\title{
Modeling the distribution of ammonia across Europe including bi-directional surface-atmosphere exchange
}

\author{
R. J. Wichink Kruit ${ }^{1}$, M. Schaap ${ }^{1}$, F. J. Sauter ${ }^{2}$, M. C. van Zanten ${ }^{2}$, and W. A. J. van Pul ${ }^{2}$ \\ ${ }^{1}$ TNO, Dept. of Climate, Air and Sustainability, P.O. Box 80015, 3508 TA Utrecht, The Netherlands \\ ${ }^{2}$ RIVM, P.O. Box 1, 3720 BA Bilthoven, The Netherlands \\ Correspondence to: R. J. Wichink Kruit (wichink@hotmail.com)
}

Received: 14 January 2012 - Published in Biogeosciences Discuss.: 24 April 2012

Revised: 10 November 2012 - Accepted: 20 November 2012 - Published: 18 December 2012

\begin{abstract}
A large shortcoming of current chemistry transport models (CTM) for simulating the fate of ammonia in the atmosphere is the lack of a description of the bi-directional surface-atmosphere exchange. In this paper, results of an update of the surface-atmosphere exchange module DEPAC, i.e. DEPosition of Acidifying Compounds, in the chemistry transport model LOTOS-EUROS are discussed. It is shown that with the new description, which includes bi-directional surface-atmosphere exchange, the modeled ammonia concentrations increase almost everywhere, in particular in agricultural source areas. The reason is that by using a compensation point the ammonia lifetime and transport distance is increased. As a consequence, deposition of ammonia and ammonium decreases in agricultural source areas, while it increases in large nature areas and remote regions especially in southern Scandinavia. The inclusion of a compensation point for water reduces the dry deposition over sea and allows reproducing the observed marine background concentrations at coastal locations to a better extent. A comparison with measurements shows that the model results better represent the measured ammonia concentrations. The concentrations in nature areas are slightly overestimated, while the concentrations in agricultural source areas are still underestimated. Although the introduction of the compensation point improves the model performance, the modeling of ammonia remains challenging. Important aspects are emission patterns in space and time as well as a proper approach to deal with the high concentration gradients in relation to model resolution. In short, the inclusion of a bi-directional surface-atmosphere exchange is a significant step forward for modeling ammonia.
\end{abstract}

\section{Introduction}

Eutrophication and acidification due to nitrogen deposition are important aspects in the conservation of ecosystems and biodiversity (Fangmeier et al., 1994; Bobbink et al., 1998). For ecosystems close to populated areas with intensive animal housing, the dry deposition of ammonia is the most important form of nitrogen input (Pitcairn et al., 1998; Walker et al., 2008). Measurements of dry deposition of ammonia, i.e. flux measurements, are however difficult and expensive. Therefore, regional, e.g. country and continental scale, estimates of dry deposition of ammonia are generally made by model calculations with atmospheric chemistry transport models (CTMs). Large uncertainties exist in the current scheme of dry deposition of ammonia in CTMs due to neglecting compensation points as well as uncertainties in the emission description (Skjøth et al., 2011). In this paper, we will investigate the effect of including compensation points for ammonia in the modeling of surface-atmosphere exchange of ammonia by CTMs.

It has long been known that ammonia is not only taken up by the surface, thus reducing its concentration in the atmosphere, but that emissions from soils and grazed pastures can also significantly contribute to the concentration of atmospheric ammonia (Denmead et al., 1978). Since then, several flux measurement campaigns have been carried out to measure ammonia fluxes over all kinds of vegetated surfaces (Flechard and Fowler, 1998; Plantaz, 1998; Milford et al., 2001a, b; Horvath et al., 2005; Wichink Kruit et al., 2007; Neirynck and Ceulemans, 2008). Even in nature areas this bi-directional behavior of ammonia has been shown (Duyzer et al., 1992; Wyers and Erisman, 1998; Nemitz et 
al., 2004; Neirynck and Ceulemans, 2008). In the 1990s, bidirectional exchange of ammonia was first included in a 1-D inferential model, which basically had the purpose to simulate the observations (Sutton et al., 1993, 1998). Based on this model approach, many simulation studies have been carried out, which increased our knowledge about the important processes that contribute to the observed net exchange of ammonia over vegetated surfaces (e.g. Smith et al., 2000; Nemitz et al., 2001; Vieno, 2005; Flechard et al., 2010; Wu et al., 2009; Zhang et al., 2010; Massad et al., 2010; Flechard et al., 2011). Although inferential models have shown that bi-directional ammonia exchange with the surface can be simulated rather well at the field scale when using detailed parameter input and some empirical tuning, the implementation of these parameterizations in CTMs is still difficult (Flechard et al., 2011). Especially the detailed process descriptions for the different exchange pathways require detailed meteorological and plant physiological parameter input, which are generally not available to regional and global CTMs. Therefore, the detailed model descriptions need to be generalized to make them applicable in CTMs. For the nonstomatal uptake and to some extent for the apoplastic ammonium content, the representation of the dependency on the pollution regime seems to be important (Nemitz et al., 2001). Wichink Kruit et al. (2010) derived a generic model description for the surface-atmosphere exchange of ammonia for the non-stomatal and stomatal pathway based on the measurement campaigns used in above-mentioned studies. This new scheme is supposed to be widely applicable, because it accounts for the local pollution climate. Note that the mass balance of $\mathrm{NH}_{3}$ and thus the local pollution regime over agricultural crops and fertilized/grazed grasslands is strongly determined by the emission of $\mathrm{NH}_{3}$, which is treated separately from the surface-atmosphere exchange between the vegetation and the atmosphere. Therefore, local variations in the type of synthetic fertilizer applied, e.g. urea vs. $\mathrm{NH}_{4} \mathrm{NO}_{3}$, the type of organic manure, the dynamics of $\mathrm{NH}_{3}$ volatilization from applied fertilizer or slurry, grazing intensity, soil microbial processes and litter decomposition all cause large uncertainties in the emission strength and consequently the mass balance over these vegetation types.

The impact of the inclusion of a bi-directional surfaceatmosphere exchange on the European ammonia budget is largely unknown. It is anticipated that both concentration distributions and deposition patterns are significantly affected. To make such an assessment requires the inclusion of the new scheme in a full CTM. As the scheme by Wichink Kruit et al. (2010) was integrated in a new version of the more general surface-atmosphere exchange module DEPAC (van Zanten et al., 2010), this is now feasible. We aim to improve the modeling of ammonia in the CTM LOTOS-EUROS and quantify the impact of the new scheme on the modeled ammonia distribution. We report a first assessment of the impact of the compensation point approach on the model results and performance.

\section{Methods}

In this section, we describe the LOTOS-EUROS chemistry transport model, the implementation of the compensation point approach, the model simulations performed and the observational data used for model evaluation.

\subsection{LOTOS-EUROS model description}

The model employed in this study is the 3-D chemistrytransport model LOTOS-EUROS (Schaap et al., 2008), which is aimed at simulating air pollution in the lower troposphere. All relevant processes are parameterized in such a way that the computational demands are modest enabling hour-by-hour calculations over extended periods of several years within acceptable CPU time of several days. Scientific studies have been performed to address secondary inorganic aerosol (Schaap et al., 2004a; Erisman and Schaap, 2004), black carbon (Schaap et al., 2004b; Schaap and Denier van der Gon, 2007), sea salt (Manders et al., 2009a, 2010), particulate matter (PM) (Manders et al., 2009b), and ozone (Vautard et al., 2006; Schaap et al., 2008). The model has participated frequently in international model comparisons aimed at ozone (Van Loon et al., 2007; Hass et al., 2003), PM (Cuvelier et al., 2007; Stern et al., 2008) and source-receptor matrices (Thunis and Cuvelier, 2008). Recently, data assimilation techniques have been used to perform assessments of the air pollution levels using an optimal combination of model and observational data (e.g. Denby et al., 2008; Barbu et al., 2009). A new direction is the use of satellite data in combination with these data assimilation techniques (van de Kassteele et al., 2006; Timmermans et al., 2010). LOTOSEUROS is used to provide daily forecasting of air pollution over Europe and the Netherlands. For a detailed description of the model, we refer to these studies. Here, we describe the most relevant model characteristics of LOTOS-EUROS version 1.7 , which is used in this study.

The model projection is normal longitude-latitude and the standard grid resolution is $0.50^{\circ}$ longitude $\times 0.25^{\circ}$ latitude, approximately $28 \times 28 \mathrm{~km}$. The actual domain for a simulation can be set, and it is possible to increase or decrease the resolution up to a factor 8 or 2 , respectively. In the vertical, the model follows the well-mixed dynamic boundary layer concept. There are three dynamic layers and a surface layer. The model extends in vertical direction $3.5 \mathrm{~km}$ above sea level. The lowest dynamic layer is the mixing layer, followed by two reservoir layers. The height of the mixing layer is obtained from the ECMWF meteorological input data used to drive the model. The height of the reservoir layers is determined by the difference between ceiling and mixing layer height. A surface layer with a fixed depth of $25 \mathrm{~m}$ is included as part of the mixing layer.

The advection in all directions is handled with the monotonic advection scheme developed by Walcek (2000). Gas phase chemistry is described using the TNO CBM-IV 
scheme, which is a condensed version of the original scheme by Whitten et al. (1980). Hydrolysis of $\mathrm{N}_{2} \mathrm{O}_{5}$ is described following Schaap et al. (2004a). Aerosol chemistry is represented using ISORROPIA (Nenes et al., 1998). The surfaceatmosphere exchange in LOTOS-EUROS is parameterized following the well-known resistance approach following the DEPAC scheme (Erisman et al., 1994). Updates to this scheme are described below. The aerodynamic resistance is calculated for all land-use types separately. Below cloud scavenging is described using simple scavenging coefficients for gases (Schaap et al., 2004a) and particles (Simpson et al., 2003).

\subsection{Changes in the surface-atmosphere exchange module}

The compensation point description for the non-stomatal and stomatal pathway of Wichink Kruit et al. (2010) was included by the National Institute for Public Health and the Environment (RIVM) in the Netherlands in an updated version of the surface-atmosphere exchange module DEPAC (Van Zanten et al., 2010), called "DEPAC3.11" hereafter. The most important difference between the previous version of the DEPAC module, called "DEPACold" hereafter, and DEPAC3.11 is that DEPACold did not explicitly account for an ammonia concentration at the surface and was mainly based on the IDEM description developed in the early 1990s (e.g. Erisman et al., 1994). DEPAC3.11 provides the possibility to account for ammonia that is present in the vegetation, water surfaces and soils, being a potential for emission under certain atmospheric conditions. Below we first summarize the main features of the DEPACold and the DEPAC3.11 module and afterwards focus on the implementation of the compensation point approach.

\subsubsection{Description of the DEPACold module}

This module was developed by Erisman et al. (1994) on the basis of experimental data. In this module, $R_{\text {stom }}$ and $R_{\text {mes }}$ represent stomatal and mesophyll resistances of leaves, respectively. $R_{\text {inc }}$ and $R_{\text {soil }}$ are resistances representing incanopy vertical transport to the soil that bypasses leaves and branches. $R_{\text {ext }}$ is an external resistance that represents deposition to non-stomatal leaf and stem surfaces, this sink being especially active when these surfaces are wet.

The DEPAC module contains default values or formulae for each of the resistances described above and for various land-use types. The module includes the gaseous components of $\mathrm{SO}_{2}, \mathrm{NO}, \mathrm{NO}_{2}$, and $\mathrm{NH}_{3}$ and provides a dry deposition velocity and a so-called effective canopy resistance on an hourly basis as a function of meteorological parameters, month of the year and time of the day. Meteorological parameters are friction velocity, Monin-Obukhov length, global radiation, wind speed at canopy height, relative humidity and a surface wetness indicator. Other parameters are land-use class, roughness length and an indicator for the $\mathrm{NH}_{3} / \mathrm{SO}_{2}$ ratio. Since its development, some of the values and formulae have been revised, with the latest version of the module described in Van Jaarsveld et al. (2004).

In contrast to what is described in Van Jaarsveld et al. (2004), the parameterization of Wesely et al. (1989) for the stomatal pathway was replaced by the parameterization of Emberson et al. (2000a, b) in LOTOS-EUROS.

\subsubsection{Description of the DEPAC3.11 module}

The surface-atmosphere exchange module DEPAC3.11 is an update of the previously described DEPAC module and includes new insights for the different exchange pathways (Van Zanten et al., 2010). The external leaf surface pathway is parameterized with the external leaf surface resistance, $R_{\mathrm{w}}$, and an external leaf surface compensation point, $\chi_{\mathrm{w}} . R_{\mathrm{w}}$ is parameterized according to Sutton and Fowler (1993), which is amongst the lowest resistances found in literature. This resistance accounts for the wetness of the surface under ideal uptake conditions, as it was derived for a rather acidic environment with optimal ammonia uptake. In the present study, the external leaf surface compensation point is parameterized as an empirical formula and is strongly dependent on the atmospheric ammonia concentration (Wichink Kruit et al., 2010; Van Zanten et al., 2010). In this way, the saturation of leaf surface water with ammonium is taken into account and the parameterization accounts for different ammonia pollution climates. The ratio between $\left[\mathrm{NH}_{4}^{+}\right]$and $\left[\mathrm{H}^{+}\right]$in the external leaf surface water, $\Gamma_{\mathrm{w}}$, is further weakly dependent on temperature, which accounts for some seasonality in $\Gamma_{\mathrm{w}}$.

The stomatal pathway is parameterized with the stomatal resistance from Emberson et al. (2000a, b), which included plant physiological and phenological processes. The stomatal compensation point is an empirical relation, which is based on many different studies over many different land-use types (see Table 5 of Wichink Kruit et al., 2010). Basically, the stomatal compensation point is assumed to be a function of the long-term ammonia concentration that accounts for the pollution climate, and a temperature function that accounts for the Henry equilibrium and dissociation. In this study, the mean ammonia concentration of the previous month is used as the long-term ammonia concentration as it best represents the average time frame of the measurement campaigns that were used to derive this empirical relation and reflects the estimated time frame for plants to respond to elevated $\mathrm{NH}_{3}$ concentration levels.

The soil pathway is extended with a soil compensation point, $\chi_{\text {soil }}$, while the original in-canopy resistance, $R_{\text {inc }}$, and soil resistance, $R_{\text {soil }}$, are maintained. As there is still a lot of uncertainty in the values for soil compensation points and to avoid double counting of emissions from the emission inventory, the soil compensation point is set to zero for the moment. Note that with this setting in DEPAC3.11 the 


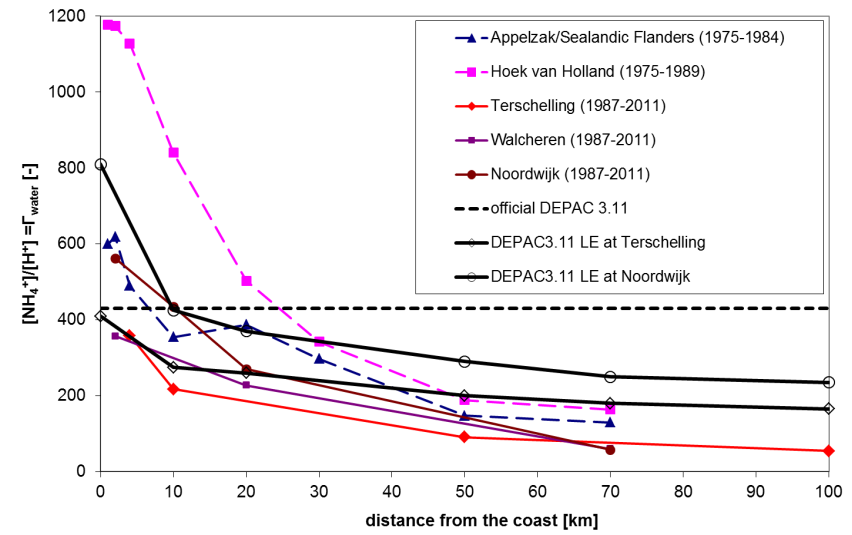

Fig. 1. Molar ratio between the $\mathrm{NH}_{4}^{+}$and $\mathrm{H}^{+}$concentration in sea water for 7 transects perpendicular to the coast in the Netherlands (data from www.waterbase.nl).

soil pathway is effectively the same as in DEPACold. DEPAC3.11 is however prepared for including the soil compensation point, although values for $R_{\text {soil }}$ might need to be adapted then.

The compensation point approach is also used for water surfaces. The ammonia exchange with the water surface is only limited by the atmospheric resistances, i.e. the aerodynamic resistances and the quasi-laminar boundary layer resistance, and the ammonia concentration just above the water surface. The ammonia concentration just above the water surface is determined by the Henry equilibrium and the dissociation of ammonium in water, which is mainly a function of temperature and the molar ratio between the $\mathrm{NH}_{4}^{+}$ and $\mathrm{H}^{+}$concentration, called $\Gamma$ hereafter. Unfortunately, we generally have no geographical distribution of $\Gamma$ values for (sea) water available. For the Netherlands, however, there exists a measurement network operated by the Dutch Rijkswaterstaat with several transects perpendicular to the coast, where $\mathrm{NH}_{4}^{+}$and $\mathrm{H}^{+}$concentrations are measured in sea water (http://www.waterbase.nl). Figure 1 shows transects at 5 locations along the Dutch coast represented by the colored lines with symbols. The data availability is not the same for all locations; for example, Appelzak and Hoek van Holland only have data in the late 1970s and early 1980s (dashed lines), but they are shown here to illustrate that $\Gamma$ values might have been reduced since then. However, Hoek van Holland is located close to the Rhine River estuary, where outflow of $\mathrm{NH}_{4}^{+}$-rich water also might have influenced these values. The figure also shows that $\Gamma$ values are higher close to the coast than further on sea, where $\Gamma$ values tend to become constant (about 50).

In the official description of DEPAC3.11 (Van Zanten et al., 2010), a fixed median value for $\Gamma$ of 430 is used together with a prescribed sea water temperature function accounting for the seasonal variation in the compensation point above sea water. This fixed $\Gamma$ value is shown by the dashed black
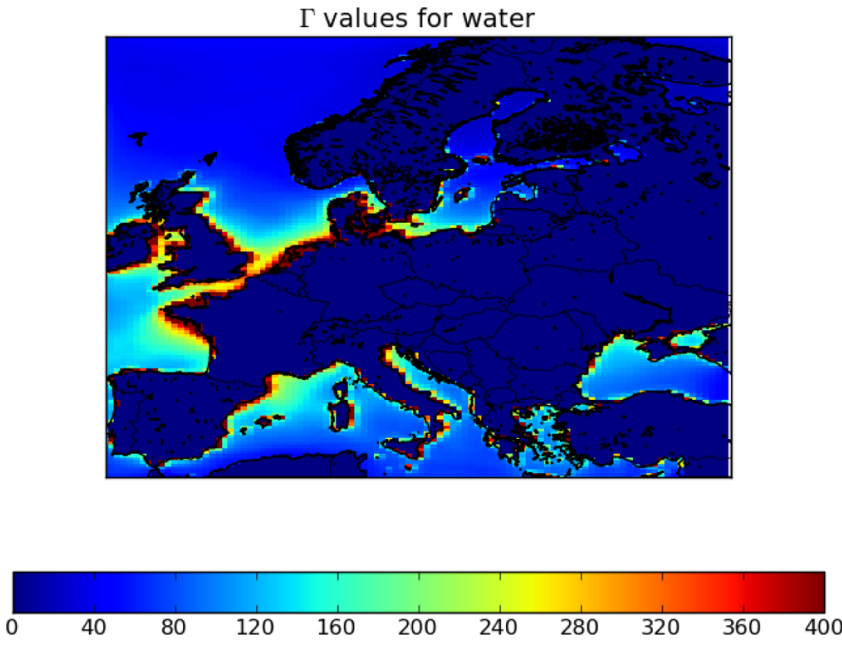

Fig. 2. Molar ratios between the $\mathrm{NH}_{4}^{+}$and $\mathrm{H}^{+}$concentration, i.e. $\Gamma$ values, in sea water as used in the LOTOS-EUROS model for the European domain. The grid resolution in this domain is $0.50^{\circ}$ longitude $\times 0.25^{\circ}$ latitude $\left(\sim 28 \times 28 \mathrm{~km}^{2}\right)$.

line in Fig. 1. This approach is valid close to the Dutch coast for which the module was originally developed, but for the European domain this assumption would lead to an overestimation of $\Gamma$ values. As a first guess for the $\Gamma$ values for the European domain in LOTOS-EUROS, we scaled the observed $\Gamma$ values with the modeled dry deposition of $\mathrm{NH}_{\mathrm{x}}$ over water from a model run without a compensation point for water (see Fig. 2). The multiplication factor by which the dry deposition of $\mathrm{NH}_{\mathrm{x}}$ [in $\mathrm{kg} \mathrm{ha}^{-1} \mathrm{yr}^{-1}$ ] is multiplied to obtain the $\Gamma$ values over water is 250 . The resulting $\Gamma$ values for two transect perpendicular to the coastline at Noordwijk (midwest of the Netherlands) and Terschelling (north of the Netherlands) are shown by the solid black lines in Fig. 1. It is shown that the $\Gamma$ values obtained from the scaling correspond better with the observed $\Gamma$ values than the fixed values in the official release of DEPAC3.11. More experimental data are needed to verify and improve the extrapolation of the North Sea data to other European seas. Also note that it might be physically more realistic to scale the observed $\Gamma$ values with the total $\mathrm{NH}_{\mathrm{X}}$ deposition instead of the dry $\mathrm{NH}_{\mathrm{x}}$ deposition only.

\subsection{Run description}

In this study we have performed two sets of LOTOS-EUROS simulations to investigate the effect of the DEPAC3.11 module on the concentration and deposition of $\mathrm{NH}_{3}$ compared to the DEPACold module. The first set is obtained with the original version of the DEPACold module and the second set with the updated surface-atmosphere exchange module DEPAC3.11. For each set we performed a simulation for 2007 on a European domain bound at $35^{\circ}$ and $70^{\circ} \mathrm{N}$ and $10^{\circ} \mathrm{W}$ and $40^{\circ} \mathrm{E}$. The grid resolution in this domain 
is $0.50^{\circ}$ longitude $\times 0.25^{\circ}$ latitude $\left(\sim 28 \times 28 \mathrm{~km}^{2}\right)$. Using a one-way zoom option, a high-resolution simulation over the Netherlands and its direct surroundings with an increase in resolution of a factor 4 has been obtained, i.e. $0.125^{\circ}$ longitude $\times 0.0625^{\circ}$ latitude $\left(\sim 7 \times 7 \mathrm{~km}^{2}\right)$

Anthropogenic emissions are prescribed following the MACC emission database (Kuenen et al., 2011). The horizontal resolution of the emission data is equal to the model resolution of the zoom run, avoiding the need to interpolate and securing consistent emissions in both model resolutions. The temporal variation of the emissions is represented by time factors. For each source category a monthly factor breaks down the annual total into monthly value. This value is divided by a factor for the day of the week and finally by a factor for the hour of the day (local time). Except for ammonia, these factors are obtained from the TROTREP project (Builtjes et al., 2003). In comparison with the emissions of $\mathrm{SO}_{\mathrm{x}}, \mathrm{NO}_{\mathrm{x}}$, and $\mathrm{VOC}$ (volatile organic compounds), the emission of ammonia is uncertain and not as well understood. Ammonia emissions in Europe are for the largest part (80-95\%) associated with agricultural activities (van der Hoek, 1998). The seasonal variation in ammonia emissions is uncertain and may differ regionally as function of farming procedures and climatic conditions. The seasonal variation in the ammonia emissions is modeled based on experimental data representative for the Netherlands (Bogaard and Duyzer, 1997; Schaap et al., 2004a). The seasonal variation shows a distinct maximum in March and a slight maximum in August due to the application of manure on top of a function that roughly scales with duration of daylight. Following Asman (2001) we assumed a diurnal cycle in the emission with half the mean value at midnight and twice the mean at noon.

\subsection{Description of measurements}

Evaluation of the model performance for ammonia and ammonium salts of nitrate and sulfate is a challenge, because there are only few measurement sites where these components are continuously monitored. For the European domain we use observations of the EMEP network. Within this network a few sites $(n=17)$ provide ammonia concentration data. However, most of the daily data are obtained by filter packs, which provide an upper limit for ammonia due to potential evaporation of ammonium nitrate from the front filter (Schaap et al., 2004c; Vecchi et al., 2009). For this reason many sites $(n=33)$ report total ammonia, which is the sum of ammonia and particulate ammonium, either obtained by means of a filter pack or an impregnated filter. Within the Netherlands, the National Air Quality Monitoring network (NAQMN; www.lml.rivm.nl) provides eight stations with hourly ammonia concentrations obtained with wet annular denuder systems (AMANDA) (Wyers et al., 1993, 1998).

A major issue for the comparison is the representation issue. Many sites in the EMEP and NAQMN networks are located in rural and agricultural areas. For many components these sites can be regarded as background, but the exception is ammonia. Many sites are prone to be influenced by nearby agricultural activities such as stables. These local sources are accounted for in the model, but the emissions are spread over the entire grid cell. Furthermore, the local heterogeneity of landscapes can affect the measurements as well as the model results. For example, in the Netherlands the annual mean concentration at agricultural sites is about $10 \mu \mathrm{g} \mathrm{m}^{-3}$ higher than in large nature areas (Stolk et al., 2009). In addition, due to the short atmospheric lifetime of ammonia, concentrations gradients are expected to be high, complicating the comparison. Fortunately, a monitoring network exists for nature areas in the Netherlands (Stolk et al., 2009). In 29 nature areas scattered throughout the Netherlands and at several locations within each nature area, passive samplers are used to monitor ammonia levels on a monthly basis. The uncertainty in the individual monthly values is large, i.e. about $20 \%$ in the high concentration range (nature areas close to agricultural areas), about $40 \%$ in the normal concentration range (most nature areas) and up to $80 \%$ in the low concentration range (coastal nature areas). The uncertainty in the annual mean concentrations from the passive samplers is lower due to the large number of measurements and is estimated to be $10-15 \%$ for inland locations and about $25 \%$ for coastal stations (Thijsse et al., 1998; Stolk et al., 2009). Therefore, we compare the model results to annual mean concentrations instead of the single monthly data points. The measurement heights in this network are variable and generally below $2.5 \mathrm{~m}$, which is the height for the modeled concentration output. As the measurement height in this network is not constant, the measured concentrations are corrected for the difference between the measurement height and the model output height using the wind profile power law, i.e. $C_{\text {obs }}\left(Z_{\text {obs }}\right) / C_{\text {obs }}\left(Z_{\text {obs }}\right)=\left(z_{\text {obs }} / z_{\text {model }}\right)^{1 / 7}$. For the model evaluation, only measurements in nature areas larger than 500 ha (approximately $2 \times 2 \mathrm{~km}$ ) are selected to avoid extremely local pollution effects. This selection reduces the number of nature areas from 29 to 18 , which is a reduction of $38 \%$, and the number of measurement locations within these nature areas from 117 to 90 , which is a reduction of $23 \%$.

Measurements over sea are extremely scarce. Therefore, we compare our model results for 2007 with the results of a measurement campaign from May 1999 to August 2000 on two different North Sea ferry routes (Tamm and Schulz, 2003). The first track is between Hamburg in Germany and Newcastle in the United Kingdom, and the second track is between Hamburg in Germany and Harwich in the United Kingdom. Each track is divided into three parts, which represent different subregions. Although the measured and modeled periods are not equal, this comparison gives us some information about the general model performance over sea. 

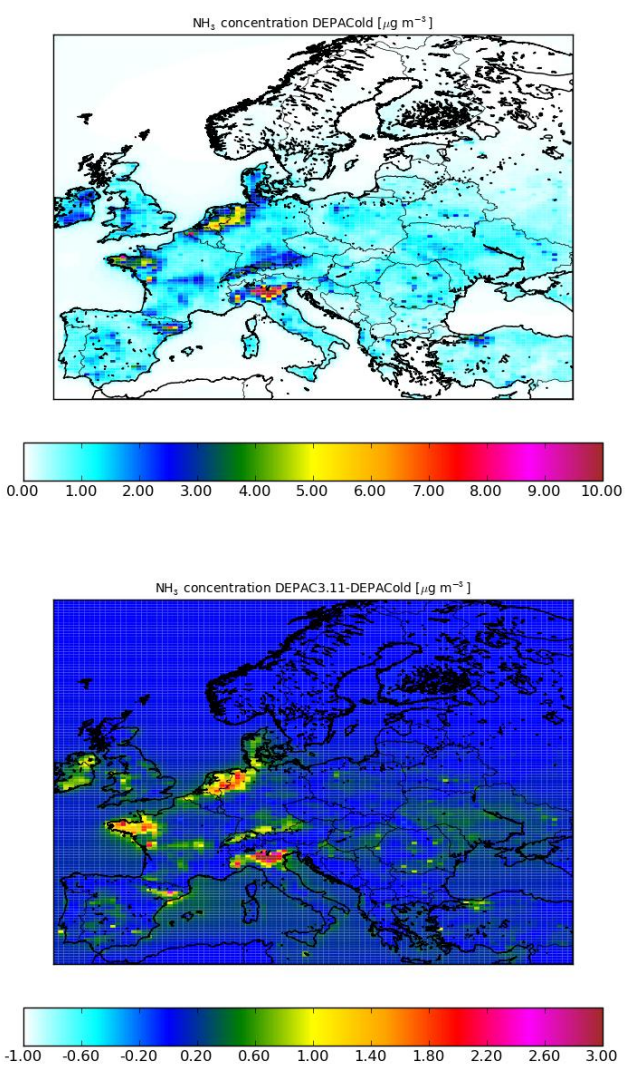
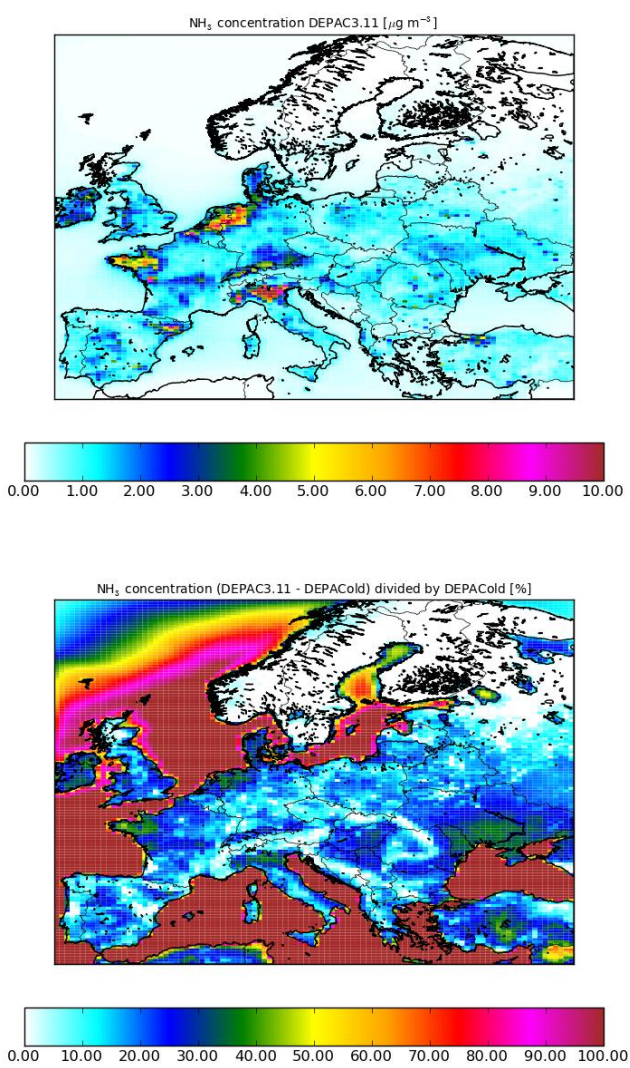

Fig. 3. The yearly mean $\mathrm{NH}_{3}$ concentrations as calculated by the LOTOS-EUROS model with the DEPACold (upper left) and DEPAC3.11 module (upper right) for the year 2007. The lower left figure shows the absolute difference, and the lower right figure shows the relative difference between the two model calculations. The grid resolution in these figures is $0.50^{\circ}$ longitude $\times 0.25^{\circ}$ latitude $\left(\sim 28 \times 28 \mathrm{~km}^{2}\right)$.

\section{Results}

In this section we describe the distributions of the annual mean ammonia concentration and surface-atmosphere exchange with the two surface-atmosphere exchange modules in the LOTOS-EUROS chemistry transport model. We evaluate these distributions with the described measurement networks and campaigns and discuss the effect on secondary inorganic aerosol formation.

\subsection{Concentration distribution}

Figure 3 shows the yearly mean $\mathrm{NH}_{3}$ concentration distribution as calculated by the LOTOS-EUROS model using DEPAC3.11 (upper right panel) and DEPACold (upper left panel) and the absolute (lower left) and relative (lower right) differences between them for the year 2007. The ammonia distribution largely follows the emission density distribution as the atmospheric lifetime of ammonia is rather short. Not surprisingly, the highest concentrations are modeled in the Po Valley, Brittany, the Netherlands and northwestern Germany with $\mathrm{NH}_{3}$ concentrations in the range of 4 to $10 \mu \mathrm{g} \mathrm{m}^{-3}$. Concentrations between 1 and $4 \mu \mathrm{g} \mathrm{m}^{-3}$ occur over large regions in central Europe, whereas lower concentrations are modeled across remote continental and marine regions. Including the compensation point approach causes the modeled ammonia concentrations to increase almost everywhere. The largest absolute increase in ammonia concentrations is observed in agricultural areas, where the increase generally amounts to $1-2 \mu \mathrm{g} \mathrm{m}^{-3}$, while in the Po Valley an increase up to $4 \mu \mathrm{g} \mathrm{m}^{-3}$ is found. In a relative sense, concentrations increase by about $30-40 \%$ in agricultural areas, whereas at a certain distance from the important source regions the increase is less than $10 \%$. In general, the transport distance and the concentration of ammonia increase everywhere. The introduction of the compensation point for water leads to the largest relative increase in the concentrations of more than $300 \%$. This is because the calculated concentrations over sea with the DEPACold scheme were very low on the order of $0.1 \mu \mathrm{g} \mathrm{m}^{-3}$.

\subsection{Surface-atmosphere exchange}

Figure 4 shows the yearly mean dry $\mathrm{NH}_{\mathrm{x}}$ deposition as calculated by the LOTOS-EUROS model using DEPAC3.11 (upper right figure) instead of the DEPACold (upper left figure) 

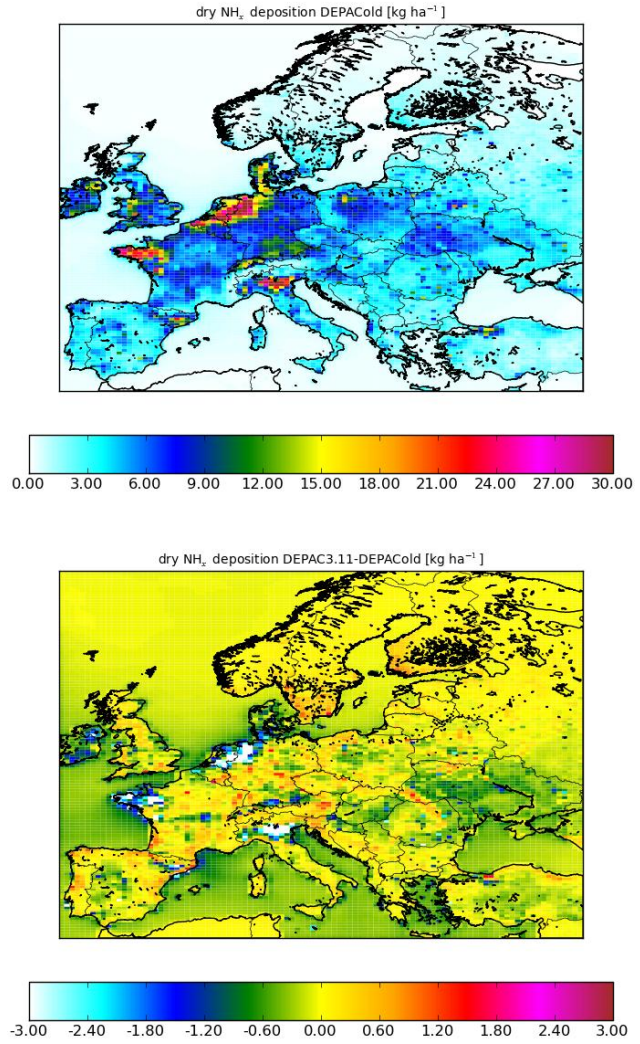
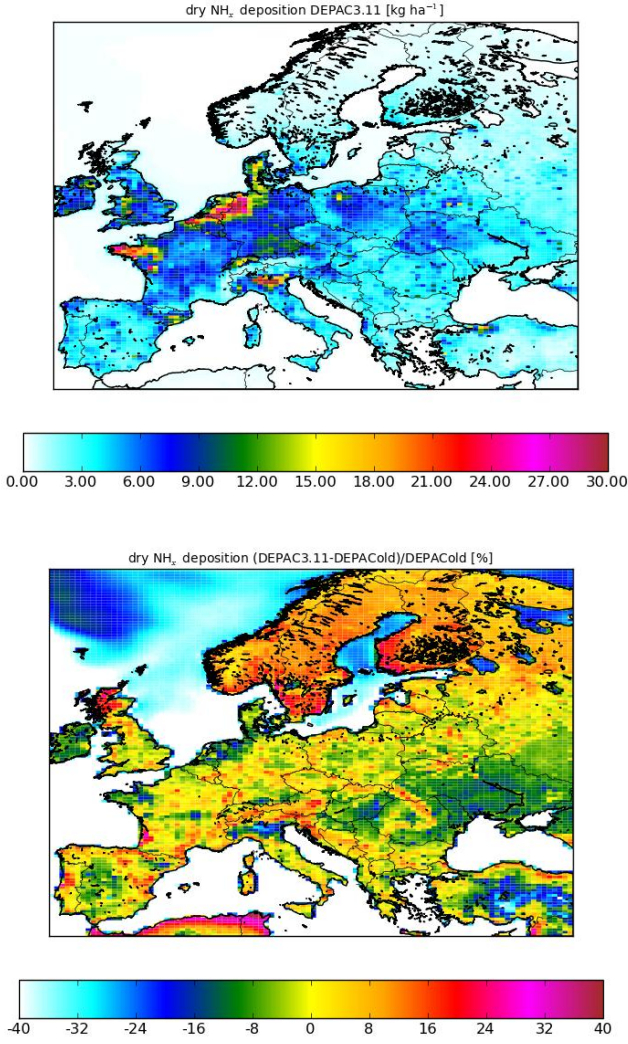

Fig. 4. The yearly mean dry $\mathrm{NH}_{\mathrm{x}}$ deposition as calculated by the LOTOS-EUROS model with the DEPACold (upper left) and DEPAC3.11 module (upper right) for the year 2007. The lower left figure shows the absolute difference, and the lower right figure shows the relative difference between the two model calculations. The grid resolution in these figures is $0.50^{\circ}$ longitude $\times 0.25^{\circ}$ latitude $\left(\sim 28 \times 28 \mathrm{~km}^{2}\right)$.

for the year 2007. The lower figures show the absolute (left) and relative (right) difference in the calculated $\mathrm{NH}_{\mathrm{x}}$ depositions with the two DEPAC schemes. The largest reductions in the $\mathrm{NH}_{\mathrm{x}}$ deposition $\left(<-2 \mathrm{~kg} \mathrm{Nha}^{-1}\right)$ are calculated in the agricultural source areas in the Netherlands, Ireland, Brittany and the Po Valley, while the largest increases are found in the larger nature areas, the more extensive rural areas and the coastal areas, especially in southern Scandinavia. This indicates that deposition is shifted towards the non-source areas. The lower right figure shows that the introduction of the compensation point for water leads to a relatively large reduction in the $\mathrm{NH}_{\mathrm{x}}$ deposition of more than $50 \%$ over sea. The figure also shows that the remote areas in Scandinavia receive up to $30 \%$ more $\mathrm{NH}_{\mathrm{x}}$. This is mainly because the concentrations in the tail of the distribution away from the main source regions are relatively more sensitive to the increase in lifetime of $\mathrm{NH}_{3}$.

The reduced dry deposition in the DEPAC3.11 scheme, due to the introduction of the compensation points, is partly compensated by an increased wet deposition due to the higher ambient air concentrations, as is shown in Fig. 5. The figure clearly shows that the wet deposition is largest close to the source areas of ammonia, but also that the wet deposition of $\mathrm{NH}_{\mathrm{x}}$ is more evenly distributed or less local than the dry deposition of $\mathrm{NH}_{\mathrm{x}}$. The absolute change in the wet deposition due to the new surface-atmosphere exchange scheme (lower left panel of Fig. 5) shows that, besides the increase in the wet deposition in the agricultural areas due to the higher ammonia concentrations, the wet deposition in the coastal areas is also increased, due to the higher ammonia concentrations over sea. This is also shown in the lower right figure in which the relative difference due to the new surface-atmosphere exchange scheme is presented. The largest relative increase in the wet deposition of $\mathrm{NH}_{\mathrm{x}}$ of more than $30 \%$ is observed over especially the Mediterranean Sea, while it is shown that the relative increase is on the order of $10-20 \%$ in the areas with the largest absolute increase and generally less than $10 \%$ in the remaining continental areas.

A comparison with wet deposition measurements in the EMEP network $(n=83)$ showed an underestimation of approximately $55 \%$ and $53 \%$ respectively for the model results with the DEPACold and DEPAC3.11 module (data not shown). Banzhaf et al. (2012) showed that this underestimation is mainly due to the lack of in-cloud scavenging in the applied scavenging scheme. 

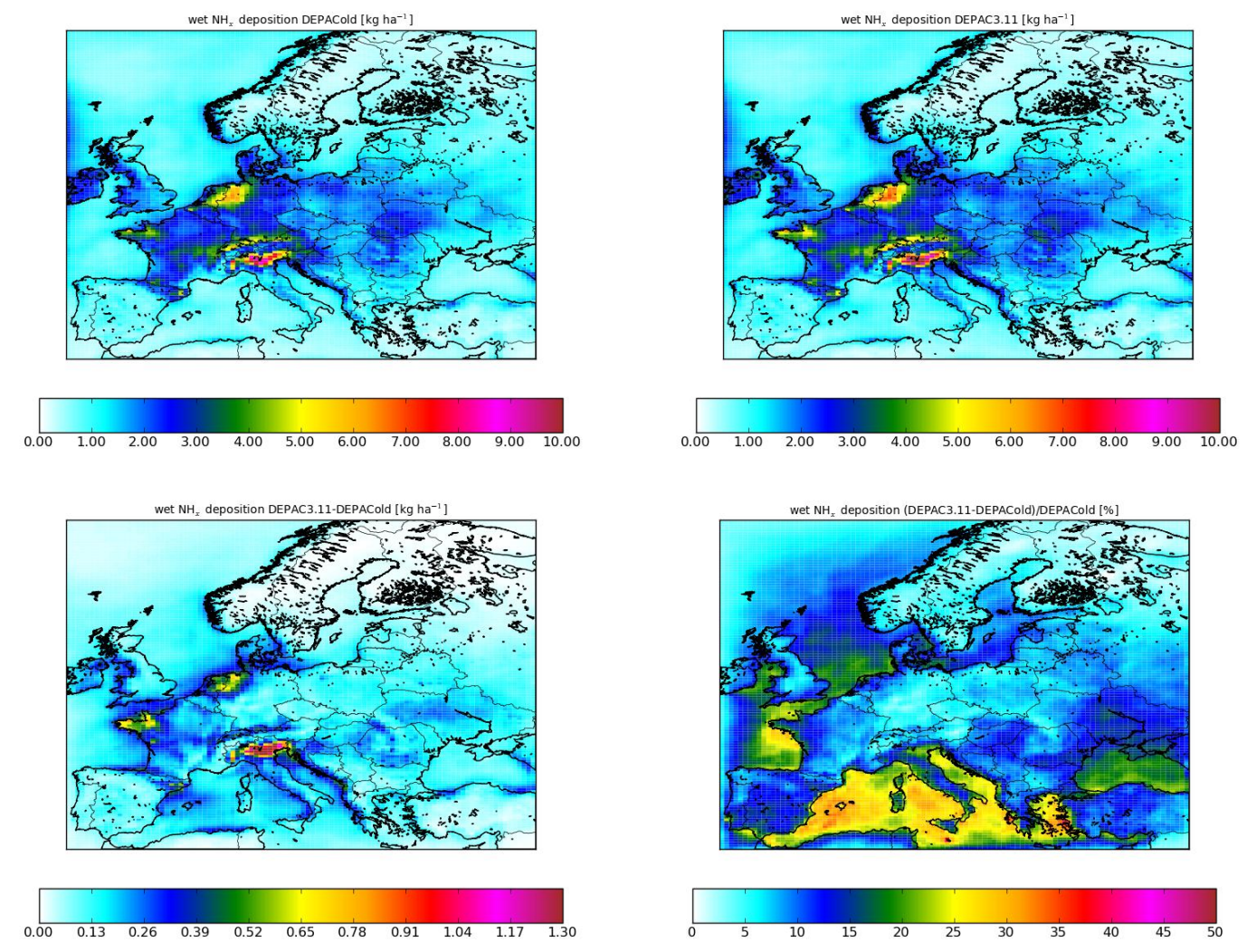

Fig. 5. The yearly mean wet $\mathrm{NH}_{\mathrm{X}}$ deposition as calculated by the LOTOS-EUROS model with the DEPACold (upper left) and DEPAC3.11 module (upper right) for the year 2007. The lower left figure shows the absolute difference, and the lower right figure shows the relative difference between the two model calculations. The grid resolution in these figures is $0.50^{\circ}$ longitude $\times 0.25^{\circ}$ latitude $\left(\sim 28 \times 28 \mathrm{~km}^{2}\right)$.

Figure 6 shows the relative contribution of the wet $\mathrm{NH}_{\mathrm{x}}$ deposition to the total $\mathrm{NH}_{\mathrm{x}}$ deposition over Europe in 2007 and illustrates that the nitrogen input by wet deposition is more important than the input by dry deposition of $\mathrm{NH}_{\mathrm{x}}$ for more remote areas and especially over sea. If we would account for the known underestimation of the modeled wet deposition, the importance of the wet deposition of $\mathrm{NH}_{\mathrm{x}}$ would even be larger in these remote and sea areas.

\subsection{Validation with measurements}

Figure 7 shows a comparison of the model runs with the DEPACold and DEPAC3.11 module with the available ammonia measurement stations (Fig. 7a) in the EMEP database and the NAQMN in the Netherlands. Figure 7b shows that the model generally underestimates the concentrations at the 24 stations. Both modules show an increasing underestimation with increasing measured ammonia levels. The stations with the largest deviations from the measurements are located in intensive agricultural areas in the eastern and southern part of the Netherlands, with annual mean measured concentrations of more than $9 \mu \mathrm{g} \mathrm{m}^{-3}$. The DEPAC3.11 module especially increases the modeled concentrations with approximately $1-2 \mu \mathrm{g} \mathrm{m}^{-3}$ at these stations, while increases in
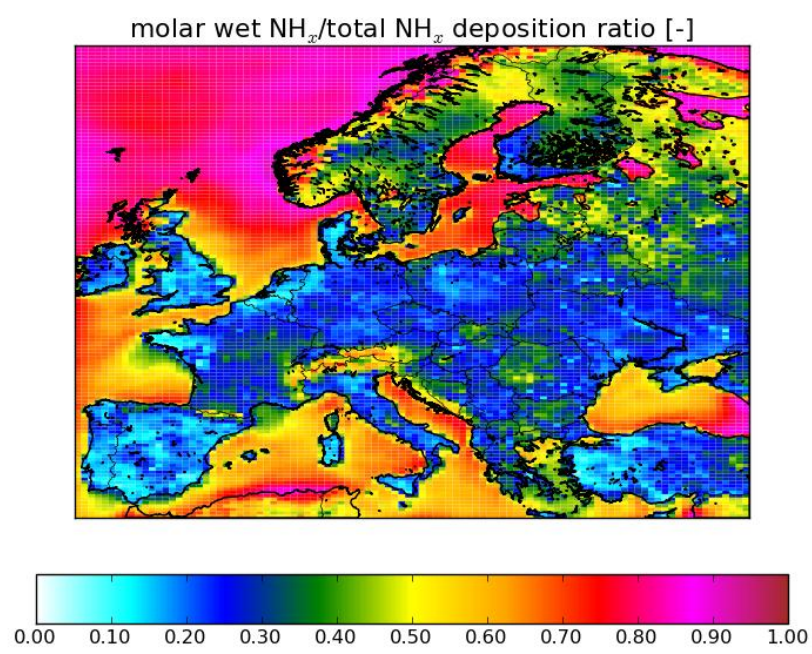

Fig. 6. Relative contribution of the wet $\mathrm{NH}_{\mathrm{x}}$ deposition to the total NHx deposition with the DEPACold module over Europe in 2007. The grid resolution in these figures is $0.50^{\circ}$ longitude $\times 0.25^{\circ}$ latitude $\left(\sim 28 \times 28 \mathrm{~km}^{2}\right)$. 

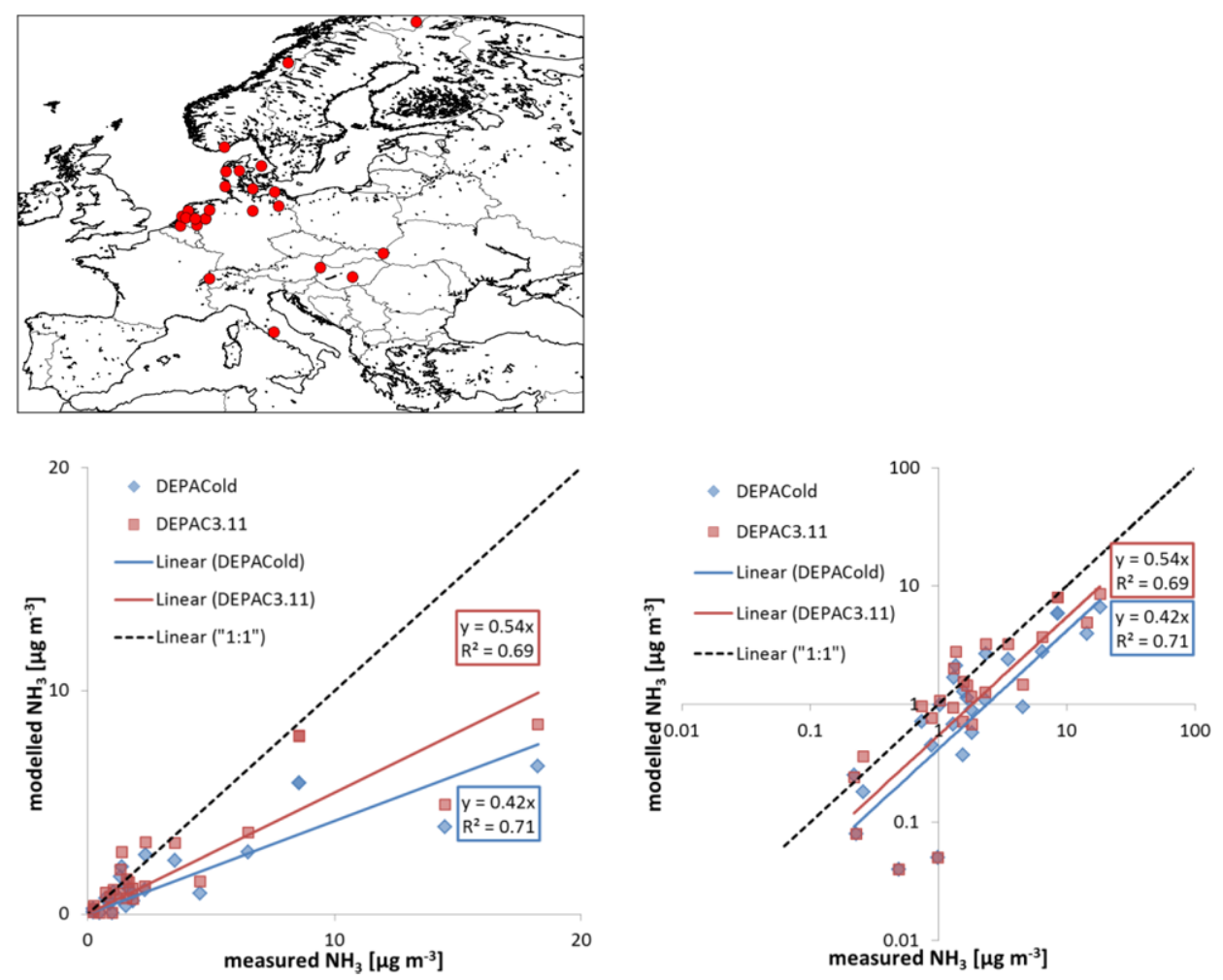

Fig. 7. Comparison of the modeled ammonia concentrations (with DEPACold and DEPAC3.11) with the measured concentrations at the available EMEP stations in Europe and the NAQMN in the Netherlands $(n=24)$ in 2007. The grid resolution of the model results is $0.50^{\circ}$ longitude $\times 0.25^{\circ}$ latitude $\left(\sim 28 \times 28 \mathrm{~km}^{2}\right)$. The upper figure shows the locations of the measurement stations; the lower left figure shows the comparison on a normal scale; the lower right figure shows the comparison on a log-log scale.

the lower concentration range are more modest. The two stations with the highest measured concentrations, being Vredepeel and Wekerom, are known to be affected by nearby pig and poultry farms, respectively, and might be less representative for the scales on which the model calculates the concentrations, i.e. approximately $50 \mathrm{~km}^{2}$. One of the stations for which both the DEPACold and the DEPAC3.11 modules overestimate the ammonia concentration is Tange in Denmark. This station is located close to a lake surrounded by forest, while the wider surroundings consist of arable lands. It is likely that the grid cell in which Tange is located in the model contains a considerable amount of agricultural land and thus emissions of ammonia, which leads to an overestimation of the annual mean concentration in this grid cell by the model. The slope of the regression between the simulated and measured concentrations is significantly improved from 0.42 to 0.54 , while the high correlation coefficient of approximately 0.7 is maintained.

Figure $7 \mathrm{~b}$ also shows that many of the measurement stations are in the concentration range between 0 and $3 \mu \mathrm{g} \mathrm{m}^{-3}$. To investigate the model performance in the low concentration range, Fig. 7c zooms in on this concentration range by using logarithmic scales. Although the improvements in the high concentration range look smaller due to the logarithmic scales, the figure nicely illustrates that the concentrations in the low concentration range are also significantly improved. Only the three stations in Norway, which have the lowest modeled concentrations, are hardly affected by the new surface-atmosphere exchange module, which is in agreement with Fig. 3. The figure also shows that the slope of the regression line is shifted towards the $1: 1$ line.

A similar picture is obtained if we compare the model results of both surface-atmosphere exchange modules with the annual mean total ammonia concentration (ammonia plus particulate ammonium) at the 33 EMEP stations in Fig. 8. Again, the largest increases occur in the higher observed concentration range. The three points with the highest observed total ammonia concentrations are Jerczew (PL), Payerne $(\mathrm{CH})$ and Els Thorms (ES), the latter two of which are located at elevation heights larger than $400 \mathrm{~m}$ with some agricultural activity in their surroundings. The slope of the regression is improved from 0.62 to 0.72 , but is strongly determined by the three points on the right-hand side of the figure. Although the slope of the regression line is closer to one, the scatter between the measurements and the model calculations is not reduced. There is, however, already a good correspondence between the measurements and model calculations, which is reflected by the high correlation coefficients of 0.77 . 

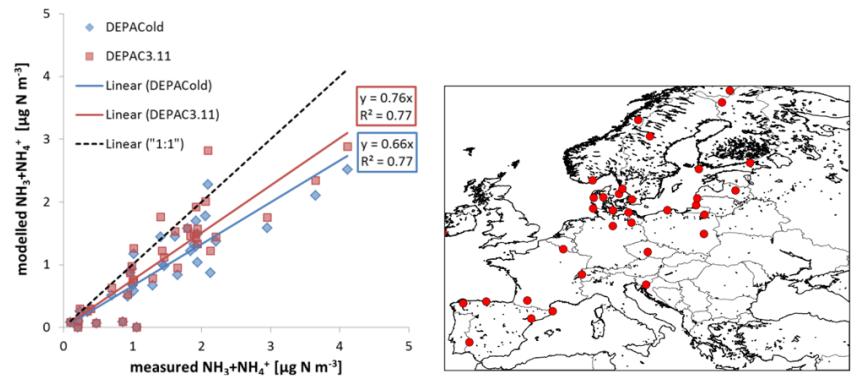

Fig. 8. Comparison of the modeled total ammonia concentrations (sum of ammonia and particulate ammonium modeled with DEPACold (red) and DEPAC3.11 (blue)) with the EMEP measurement stations $(n=33)$ in Europe in 2007. The grid resolution of the model results is $0.50^{\circ}$ longitude $\times 0.25^{\circ}$ latitude $\left(\sim 28 \times 28 \mathrm{~km}^{2}\right)$.

Figure 9 shows a comparison of the model results with measurements of the Monitoring network of Ammonia in Nature areas (MAN) in the Netherlands, a passive sampler network operated by RIVM (Stolk et al., 2009). Only nature areas larger than 500 ha were considered in this analysis, as the smaller areas are considered to be influenced by nearby sources too much. The figure shows that the LOTOSEUROS model underestimates the ammonia concentrations in the nature areas by about $12 \%$ with the DEPACold module. This underestimation is consistent with the previous figures. However, the model overestimates the concentrations in nature areas with the DEPAC 3.11 module by about $13 \%$. These biases are on the same order of magnitude as the uncertainty in the measurements, which is estimated to be $10 \%$ for the annual average values (Stolk et al., 2009). A possible reason for the overestimation by the DEPAC3.11 module is likely that the horizontal grid size resolution of the model is generally larger than the size of nature areas, such that most grid cells contain ammonia emissions, which are spread over the grid cell and consequently raise the concentration in the grid cell. If a selection of nature areas larger than 2000 ha is made, which is approximately $4.5 \times 4.5 \mathrm{~km}^{2}$, only 10 out of the 29 nature areas remain in the selection and less than $50 \%$ of the measurement locations stay in the comparison. Besides, most of the nature areas in the MAN network are located in the southeast and east of the Netherlands, which are the most intensive agricultural parts of the country. Stolk et al. (2009) found a strong dependency between the distance to the edge of the nature area and the concentration, especially for the nature areas that are exposed to higher ammonia levels. Locations close to the border of the nature area, i.e. close to agricultural land, show much higher concentrations than sites in the middle of the nature areas. The largest distance in the MAN network to the border of the nature area is generally less than $10 \mathrm{~km}$, but the majority of the measurements, especially the ones that are exposed to the higher ammonia levels, are located less than $5 \mathrm{~km}$ away from the border. This is less than the $7 \times 7 \mathrm{~km}^{2}$ grid size resolution of the model, which
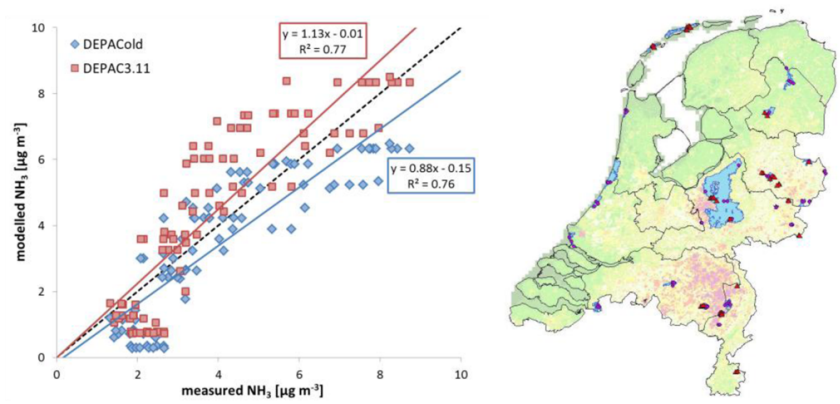

Fig. 9. Model comparison of annual mean ammonia concentrations modeled with LOTOS-EUROS using the two surface-atmosphere exchange modules and measurements of the Monitoring network of Ammonia in Nature areas larger than 500 ha in the Netherlands in 2007 (Stolk et al., 2009). The grid resolution of the model results is $0.125^{\circ}$ longitude $\times 0.0625^{\circ}$ latitude $\left(\sim 7 \times 7 \mathrm{~km}^{2}\right)$.

supports the above explanation for the overestimations of the concentrations by the model. In the low concentration range $\left(<3 \mu \mathrm{g} \mathrm{m}^{-3}\right)$, there is a cluster of 26 coastal measurement points (out of 90 in total) that was largely underestimated with the DEPACold module. This cluster is much better modeled with the DEPAC3.11 module, due to the introduction of the compensation point for water, which increases the background concentration at these coastal stations.

Figure 10 shows the comparison of the modeled ammonia concentrations for 2007 using the DEPACold (upper figures) and DEPAC3.11 (lower figures) surface-atmosphere exchange modules with the measured ammonia concentrations of the NitroEurope measurement network $(n=55)$ for 2007-2008 (reported by Flechard et al., 2011). The measurement stations in this network are rather equally distributed over Europe and cover roughly four different landuse classes, i.e. forest, semi-natural, grassland and crop, which are marked with different colors and symbols. The left figure, which shows the comparison between the model results with the DEPACold module and the measurements of the NitroEurope network, shows a similar underestimation as we have seen in Figs. 7 and 8. The underestimation is mainly caused by the "crop" locations and results in low correlation coefficients. Removing the "crop" locations from the comparison results in a slope of 1.05 and a correlation coefficient of 0.56 . The comparison of the model results obtained with the DEPAC3.11 module with the measurements of the NitroEurope network (right figure) shows that the overall underestimation is reduced similar to what we have seen in Figs. 7 and 8. If we exclude the "crop" locations from this analysis, we even see an overestimation of the ammonia concentrations for the semi-natural and forest locations with a slope of 1.30 and a correlation coefficient of 0.61 , which shows some similarity with the comparison of the model results with the Monitoring network of Ammonia in Nature areas in the Netherlands (Fig. 9). Note that we 

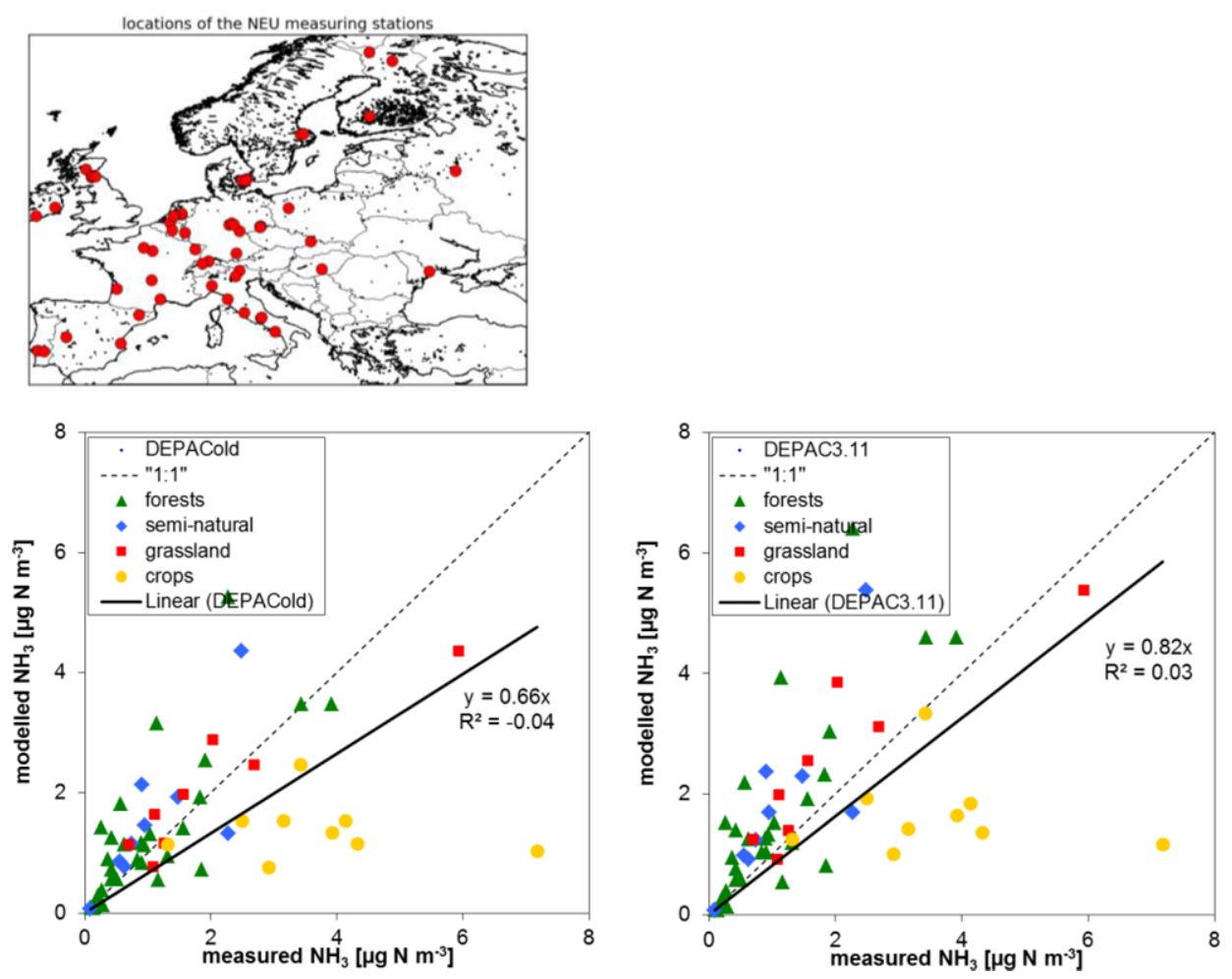

Fig. 10. Comparison of the modeled ammonia concentrations for 2007 using the DEPACold (left figure) and DEPAC3.11 (right figure) surface-atmosphere exchange modules with the measured concentrations of the NitroEurope measurement network $(n=55)$ for $2007-2008$ (Flechard et al., 2011). The grid resolution of the model results is $0.50^{\circ}$ longitude $\times 0.25^{\circ}$ latitude $\left(\sim 28 \times 28 \mathrm{~km}^{2}\right)$. The stations in the NitroEurope network are classified into four different land-use classes (forest, semi-natural, grassland and crops).

compare model results for 2007 with arithmetic means for the period 2007-2008 of the NitroEurope network.

To further investigate the model behavior at coastal stations, we focus at the EMEP station in Westerland in Germany for which daily data are available. We show the time series in Fig. 11 and the corresponding scatter plot in Fig. 12. Figure 11 shows that the observed underestimation of ammonia concentrations is partly reduced by the introduction of the compensation point for sea water in DEPAC3.11. The DEPAC3.11 module gives a background concentration of approximately $0.5-1.0 \mu \mathrm{g} \mathrm{m}^{-3}$ in summer and autumn, while the background concentration was almost zero with the DEPACold module. The peaks occurring during offshore wind episodes are caused by agricultural activities. The timing of the main events is rather well reproduced by the model, but it also shows that although the compensation point is an improvement, there are additional challenges remaining to improve the modeling of ammonia. Despite the improvements from the DEPAC3.11 module, the modeled concentrations at Westerland are still more than a factor 2 too low.

In Fig. 13, we compare the model results with the two surface-atmosphere exchange schemes for 2007 with the data of a 15 months measurement campaign at two North
Sea ferry routes from May 1999 to August 2000 (data from Tamm and Schulz, 2003).

It is obvious that the modeled concentrations over the North Sea have significantly increased by the DEPAC3.11 module. With the DEPACold module, the concentrations fell off rather quickly from values higher than $1.0 \mu \mathrm{g} \mathrm{m}^{-3}$ on land to values below $0.2 \mu \mathrm{g} \mathrm{m}^{-3}$ further offshore. With the DEPAC3.11 module, concentrations decrease more gradually due to the reduced deposition on water, which is the result of the compensation point for water. The displayed values represent the median concentrations for the different subregions during the whole measurement campaign (Tamm and Schulz, 2003). As it is difficult to designate a single model point or a cluster of model points to a subregion, we roughly evaluate the surroundings of the displayed values. The colors in the symbols correspond to the color scale in the color bar. We can conclude that a significant part of the gap between observed and modeled concentrations is closed by the introduction of DEPAC3.11 module. The median values compare better with the modeled fields than the mean values, which are also given in Tamm and Schulz (2003), especially for the two most northerly points. This is likely due to a few high concentration events during the measurement campaign, which is expressed by the maximum observed concentrations 


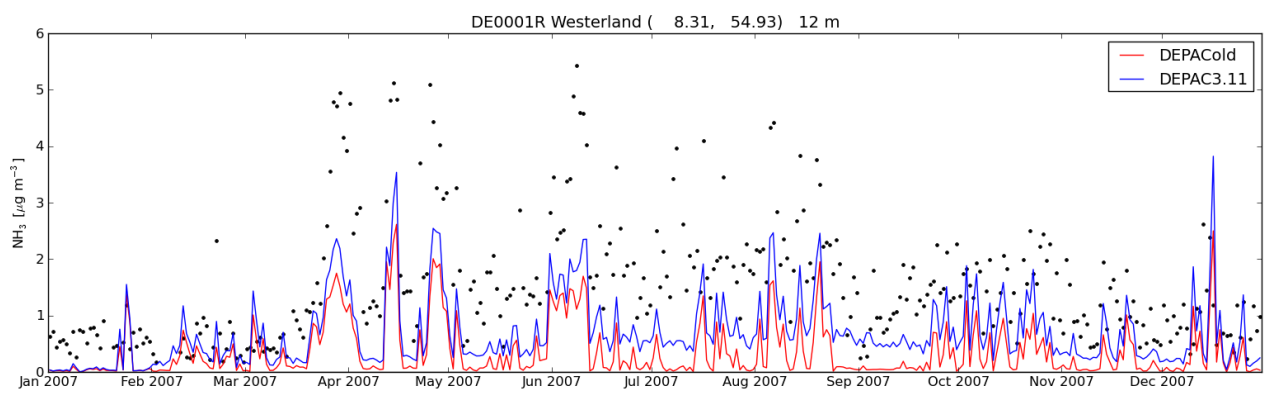

Fig. 11. Time series for the measured and modeled ammonia concentrations with the DEPACold module (red line) and the DEPAC 3.11 module (blue line) at EMEP station Westerland in Germany in 2007. Black dots are the daily measurements. The grid resolution of the model results is $0.50^{\circ}$ longitude $\times 0.25^{\circ}$ latitude $\left(\sim 28 \times 28 \mathrm{~km}^{2}\right)$.

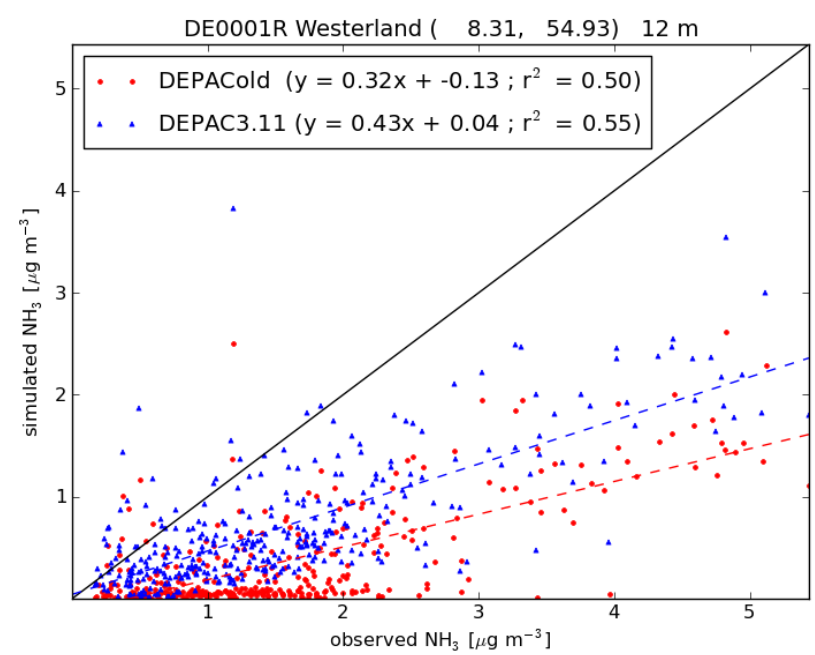

Fig. 12. Scatter plot for the daily mean measured and modeled ammonia concentrations with the DEPACold module (red dots) and the DEPAC3.11 module (blue dots) at EMEP station Westerland in Germany in 2007. The grid resolution of the model results is $0.50^{\circ}$ longitude $\times 0.25^{\circ}$ latitude $\left(\sim 28 \times 28 \mathrm{~km}^{2}\right)$.

of 4.5 and $3.4 \mu \mathrm{g} \mathrm{m}^{-3}$ in the upper left and upper middle subregions, respectively.

\subsection{Effects on secondary inorganic aerosol (SIA) components}

Although the increase in the ammonia concentrations is large in some agricultural areas, the effect on the secondary inorganic aerosol (SIA) formation, i.e. $\mathrm{NH}_{4} \mathrm{NO}_{3}, \mathrm{NH}_{4} \mathrm{HSO}_{4}$ and $\left(\mathrm{NH}_{4}\right)_{2} \mathrm{SO}_{4}$, is rather limited. Over land, the changes in modeled annual mean concentrations due to the use of DEPAC3.11 instead of the DEPACold are generally lower than $0.1 \mu \mathrm{g} \mathrm{m}^{-3}$. The right panel in Fig. 13 shows the influence of one of the updates in the DEPAC 3.11 module that was not mentioned before. The surface resistance of $\mathrm{SO}_{2}$ was reduced to harmonize the DEPAC versions used in OPS and LOTOS-
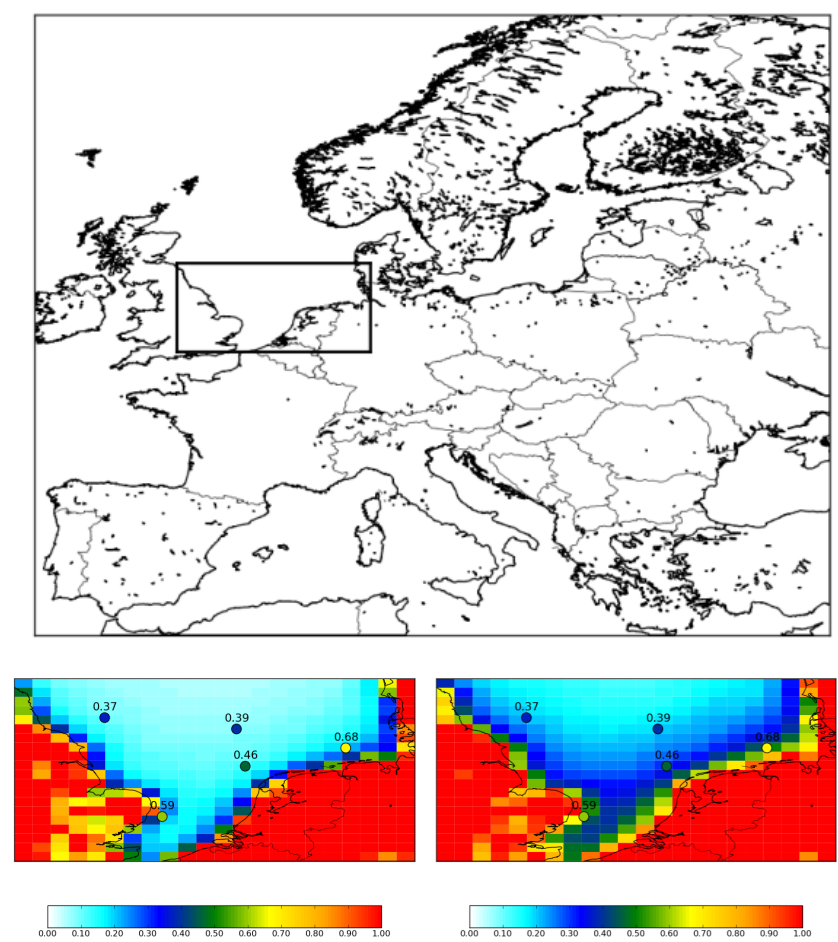

Fig. 13. The yearly mean $\mathrm{NH}_{3}$ concentrations as calculated by the LOTOS-EUROS model with the DEPACold (left) and DEPAC3.11 module (right) for the year 2007 zoomed in on the North Sea and focusing on the lower concentration range between 0 and $1 \mu \mathrm{g} \mathrm{m}^{-3}$. The median concentrations of the measurement campaign are displayed as numbers in the modeled distributions. The grid resolution of the model results is $0.50^{\circ}$ longitude $\times 0.25^{\circ}$ latitude $\left(\sim 28 \times 28 \mathrm{~km}^{2}\right)$.

EUROS model. This update generally resulted in lower atmospheric $\mathrm{SO}_{2}$ concentrations due to larger deposition and led to a small reduction in the $\mathrm{SO}_{4}^{2-}$ concentrations of less than $0.15 \mu \mathrm{g} \mathrm{m}^{-3}$. The reduction in $\mathrm{SO}_{4}^{2-}$ concentrations also led to a small reduction in the $\mathrm{NH}_{4}^{+}$concentrations in southern Germany, Austria and northern Italy. 

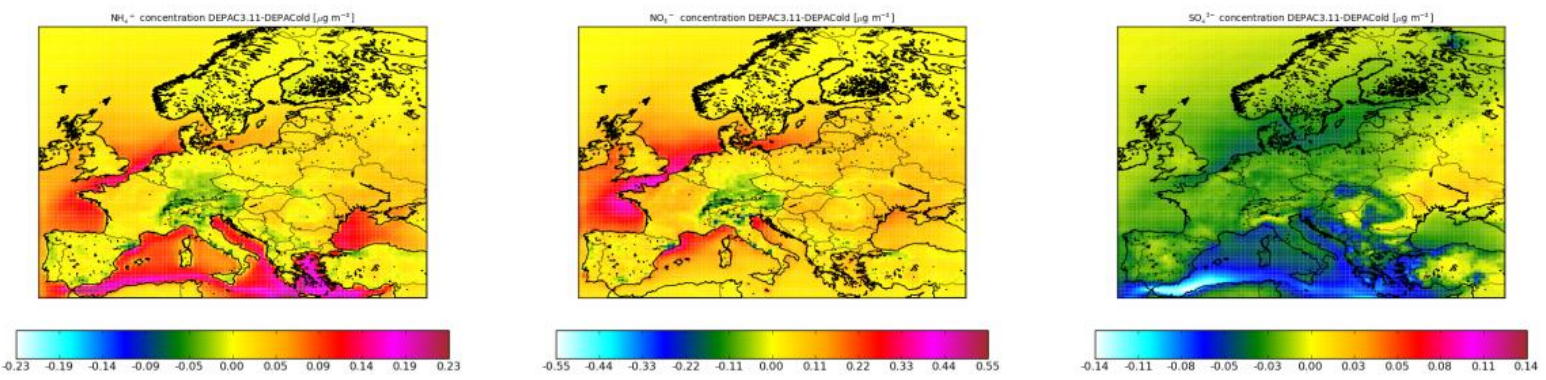

Fig. 14. Absolute difference in the $\mathrm{NH}_{4}^{+}$(left), $\mathrm{NO}_{3}^{-}$(middle) and $\mathrm{SO}_{4}^{2-}$ (right) concentration due to the use of DEPAC3.11 instead of the DEPACold module for the year 2007. The grid resolution of the model results is $0.50^{\circ}$ longitude $\times 0.25^{\circ}$ latitude $\left(\sim 28 \times 28 \mathrm{~km}^{2}\right)$.

Interestingly, over the Mediterranean Sea the atmospheric $\mathrm{NH}_{4}^{+}$concentrations increase while the $\mathrm{SO}_{4}^{2-}$ concentrations decrease and the $\mathrm{NO}_{3}^{-}$concentrations remain very low. This seems to be rather contradictory, but it is explained by the fact that the sulfate in the base case is not fully neutralized. Hence, the ammonia background over sea causes more ammonia to be converted to particulate ammonium. All available $\mathrm{NH}_{3}$ reacts with $\mathrm{H}_{2} \mathrm{SO}_{4}$, and therefore the $\mathrm{NO}_{3}^{-}$concentrations are not really affected here. Only in northwestern Europe, the increase in ammonia concentrations results in more $\mathrm{NH}_{4} \mathrm{NO}_{3}$ formation over sea.

The changes in the modeled SIA concentrations over land are small; as all measurement stations are located here, the improvement of the model performance of LOTOS-EUROS is marginal over land (not shown).

\section{Discussion and conclusions}

This study is among the first to implement the compensation point approach in a regional CTM. Although inferential models (Flechard et al., 2011) have shown that bi-directional ammonia exchange with the surface can be simulated rather well nowadays, the implementation of these parameterizations in CTMs is still difficult. Especially the detailed process descriptions for the different exchange pathways require detailed meteorological, plant physiological and soil parameter input, which is generally not available for regional and global CTMs. Therefore, the detailed model descriptions need to be generalized to make them applicable in CTMs. Recently, several attempts have been made to derive and implement generalized parameterizations, e.g. Massad et al. (2010), Zhang et al. (2010); Bash et al. (2012). The generalization step is often a shortcoming as parameterizations are derived for just one certain land-use class that is located in one certain pollution climate. Especially the pollution climate seems to be important, because the surface in polluted areas becomes saturated with ammonia and the uptake of ammonia at the surface is reduced. Therefore a strong link between the surface-atmosphere exchange of ammonia and pollution climate seems to be obvious. Nemitz et al. (2001) found a log-linear relation between the external leaf surface resistance and the pollution climate through a factor $\alpha_{\mathrm{SN}}$, which is the ratio between $\mathrm{SO}_{2}$ and $\mathrm{NH}_{3}$ concentration. In this study, the pollution climate is taken into account by including the mean ambient ammonia concentration of the previous month for the stomatal compensation point and the ambient ammonia concentration of the previous hour for the external leaf surface concentration. However, we did not explicitly account for the co-deposition effect of $\mathrm{NH}_{3}$ and $\mathrm{SO}_{2}$ yet. In the Netherlands $\mathrm{SO}_{2}$ concentrations and consequently the ratio between the molar $\mathrm{SO}_{2}$ and $\mathrm{NH}_{3}$ concentrations are generally very low $(<0.1)$ and are not expected to influence the $\mathrm{NH}_{3}$ uptake much in the Netherlands, for which the module was originally developed. For the European domain, this could be important though, because especially in Eastern Europe $\mathrm{SO}_{2}$ concentrations can be relatively high, making the surface more acidic and therefore more favorable for uptake of ammonia.

RIVM showed that the DEPAC3.11 module in the Lagrangian OPS model reduces the previous underestimation of the modeled $\mathrm{NH}_{3}$ concentrations in the Netherlands almost completely and results in approximately $20 \%$ higher concentrations compared to previous calculations with the DEPACold module (Van Pul et al., 2008). In this study, the DEPAC3.11 module (compared to the DEPACold module) in the Eulerian LOTOS-EUROS model results in an increase in the $\mathrm{NH}_{3}$ concentrations of up to $30-40 \%$ in the most intensive agricultural areas. Over sea, increases are much larger (> $300 \%$ in the Mediterranean Sea), because the compensation point for sea water in DEPAC3.11 was not present in the DEPACold module. The limited numbers of measurements that are available over sea indicate that the concentrations with the DEPAC3.11 module are more realistic than the concentrations of almost zero with the DEPACold module (Tamm and Schulz, 2003). The introduction of a compensation point for sea water also resulted in a higher and more realistic background concentration at coastal measurement stations. As well for the coastal measurement stations in the MAN network in the Netherlands as for the EMEP station Westerland in Germany, the concentrations are much 
better represented when using the DEPAC3.11 module in the LOTOS-EUROS model. The concentrations still appear to be on the low side, which suggests that we might have been too conservative in the choice of the scaling factor of 250 to derive $\Gamma$ values for sea water from the dry deposition of $\mathrm{NH}_{\mathrm{x}}$. However, the potentially large effect of the outflow of $\mathrm{NH}_{4}^{+}$-rich water from estuaries on the $\Gamma$ values is not taken into account. Altogether, the first-order approximation to use a scaling of the dry deposition of $\mathrm{NH}_{\mathrm{x}}$ for the $\Gamma$ values for sea water is successful.

Comparison between the LOTOS-EUROS model results and measurements showed that, with the DEPAC3.11 module, the $\mathrm{NH}_{3}$ concentrations are slightly overestimated in nature areas and underestimated in source regions. Several studies in the UK showed that significant differences may occur between measured and modeled ammonia concentrations due to the grid size resolution. The modeled mean concentration from a $7 \times 7 \mathrm{~km}^{2}$ model grid cell may therefore significantly differ from the measured concentration at a specific location within the grid cell. Especially, the highly localized nature of $\mathrm{NH}_{3}$ emissions is causing this difference (Dragosits et al., 2002; Dore et al., 2007; Van Pul et al., 2009). These studies have also shown that a further increase in resolution enables better discrimination between agricultural and natural areas. However, using such resolutions for the full European domain is computationally expensive. A potential way out may be to keep track of the local contribution within each grid cell using a source apportionment tool such as developed by Wagstrom et al. (2008) and compare the non-local part of the total modeled concentration to the nature areas. Alternatively, the plume in grid approach (e.g. Geels et al., 2012) may provide a good means to overcome the scale issues involved in the modeling of ammonia.

Despite the generally higher $\mathrm{NH}_{3}$ concentrations, the concentrations of the secondary inorganic aerosol (SIA) components, which are in thermodynamic equilibrium with ammonia, are only slightly affected over land (less than $10 \%$ difference). Especially close to the coast, the $\mathrm{NH}_{4}^{+}$and $\mathrm{NO}_{3}^{-}$ concentrations appear to be higher due to more $\mathrm{NH}_{4} \mathrm{NO}_{3}$ formation. Due to a smaller surface resistance for $\mathrm{SO}_{2}$ in the DEPAC3.11 module, the $\mathrm{SO}_{2}$ and consequently the $\mathrm{H}_{2} \mathrm{SO}_{4}$ concentrations decrease almost everywhere. Due to the lack of $\mathrm{H}_{2} \mathrm{SO}_{4}$, there is a decrease in the $\mathrm{SO}_{4}^{2-}$ formation, which also resulted in a decrease of $\mathrm{NH}_{4}^{+}$in southern Germany, Austria and northern Italy, as not sufficient $\mathrm{HNO}_{3}$ is available to replace the $\mathrm{H}_{2} \mathrm{SO}_{4}$. As a consequence, $\mathrm{NH}_{3}$ concentrations in these areas will be slightly higher, but it is difficult to distinguish how much of the observed increase is caused by the compensation points for ammonia or by the reduced surface resistance for $\mathrm{SO}_{2}$.
Acknowledgements. Some observational data that are used for model validation in this study were generated or collected within the framework of the NitroEurope IP, project 017841 . The authors are grateful to all environmental chemists and scientists involved in running the DELTA network and Chris Flechard in particular, who made the data available through his paper. This work is sponsored by the German Federal Environment Agency (Umweltbundesamt, Germany) and the Dutch Ministry of Infrastructure and the Environment.

Edited by: E. Nemitz

\section{References}

Asman, W. A. H.: Modelling the atmospheric transport and deposition of ammonia and ammonium: an overview with special reference to Denmark, Atmos. Environ., 35, 1969-1983, 2001.

Banzhaf, S., Schaap, M., Kerschbaumer, A., Reimer, E., Stern, R., van der Swaluw, E., Builtjes, P.: Implementation and evaluation of pH-dependent cloud chemistry and wet deposition in the chemical transport model REM-Calgrid, Atmos. Environ., 49, 378-390, doi:10.1016/j.atmosenv.2011.10.069, 2012.

Barbu, A. L., Segers, A. J., Schaap, M., Heemink, A. W., and Builtjes, P. J. H.: A multi-component data assimilation experiment directed to sulphur dioxide and sulphate over Europe, Atmos. Environ., 43, 1622-1631, 2009.

Bash, J. O., Cooter, E. J., Dennis, R. L., Walker, J. T., and Pleim, J. E.: Evaluation of a regional air-quality model with bi-directional NH3 exchange coupled to an agro-ecosystem model, Biogeosciences Discuss., 9, 11375-11401, doi:10.5194/bgd-9-113752012, 2012.

Bobbink, R., Hornung, M., and Roelofs, J. G. M.: The effects of air-borne nitrogen pollutants on species diversity in natural and semi-natural European vegetation, J. Ecol., 86, 717-738, 1998.

Bogaard, A. and Duyzer, J.: Een vergelijking tussen resultaten van metingen en berekeningen van de concentratie van ammoniak in de buienlucht op een schaal kleiner dan 5 kilometer, TNO-report, TNO-MEP-R97/423, Apeldoorn, The Netherlands, 1997.

Builtjes, P. J. H., van Loon, M., Schaap, M., Teeuwisse, S., Visschedijnk, A. J. H., and Bloos, J. P.: Project on the modeling and verification of ozone reduction strategies: contribution of TNO-MEP, TNO-report, TNO-MEP-R2003/166, Apeldoorn, The Netherlands, 2003.

Cuvelier, C., Thunis, P., Vautard, R., Amann, M., Bessagnet, B., Bedogni, M., Berkowicz, R., Brandt, J., Brocheton, F., Builtjes, P., Coppalle, A., Denby, B., Douros, G., Graf, A., Hellmuth, O., Honoré, C., Hodzic, A., Jonson, J., Kerschbaumer, A., de Leeuw, F., Minguzzi, E., Moussiopoulos, N., Pertot, C., Pirovano, G., Rouil, L., Schaap, M., Stern, R., Tarrason, L., Vignati, E., Volta, M., White, L., Wind, P., and Zuber, A.: CityDelta: A model intercomparison study to explore the impact of emission reductions in European cities in 2010, Atmos. Environ., 41, 189-207, 2007.

Denby, B., Schaap, M., Segers, A., Builtjes, P., and Horalek, J.: Comparison of two data assimilation methods for assessing $\mathrm{PM}_{10}$ exceedances on the European scale, Atmos. Environ., 42, 7122-7134, 2008.

Denmead, O. T., Nulsen, R., and Thurtell, G. W.: Ammonia exchange over a corn crop, Soil Sci. Soc. Am. J., 42, 840-842, 1978. 
Dore, A. J., Theobald, M. R., Vieno, M., Tang, Y. S., and Sutton, M. A.: Modelling of ammonia concentrations and deposition of reduced nitrogen in the United Kingdom. Proceedings of the 11th International Conference on Harmonisation within Atmospheric Dispersion Modelling for Regulatory Purposes, Cambridge, UK, 266-270, 2007.

Dragosits, U., Theobald, M. R., Place, C. J., Lord, E., Webb, J., Hill, J., ApSimon, H. M., and Sutton, M. A.: Ammonia emissions, deposition and impact assessment at the field scale: a case study of sub-grid spatial variability, Environ. Pollut., 117, 147-158, 2002.

Duyzer, J. H., Verhagen, H. L. M., Weststrate, J. H., and Bosveld, F. C.: Measurement of the dry deposition flux of $\mathrm{NH}_{3}$ on to coniferous forest, Environ. Pollut., 75, 3-13, 1992.

Emberson, L. D., Ashmore, M. R., Simpson, D., Tuovinen, J.-P., and Cambridge, H. M.: Towards a model of ozone deposition and stomatal uptake over Europe. EMEP/MSC-W 6/2000, Norwegian Meteorological Institute, Oslo, Norway, 57 pp., 2000a.

Emberson, L. D., Ashmore, M. R., Simpson, D., Tuovinen, J.-P., and Cambridge, H. M.: Modelling stomatal ozone flux across Europe, Water Air Soil Pollut., 109, 403-413, 2000b.

Erisman, J. W. and Schaap, M.: The need for ammonia abatement with respect to secondary PM reductions in Europe, Environ. Pollut., 129, 159-163, 2004.

Erisman, J. W., Van Pul, W. A. J., and Wyers, P.: Parameterization of surface resistance for the quantification of atmospheric deposition of acidifying compounds and ozone, Atmos. Environ., 28, 2595-2607, 1994.

Fangmeier, A., Hadwiger-Fangmeier, A., van der Eerden, L., and Jaeger, H. J.: Effects of atmospheric ammonia on vegetation - a review, Environ. Pollut., 86, 43-82, 1994.

Flechard, C. R. and Fowler, D.: Atmospheric ammonia at a moorland site, II: Long-term surface-atmosphere micrometeorological flux measurements, Q. J. Roy. Meteorol. Soc., 124, 759-791, 1998.

Flechard, C. R., Spirig, C., Neftel, A., and Ammann, C.: The annual ammonia budget of fertilised cut grassland - Part 2: Seasonal variations and compensation point modeling, Biogeosciences, 7 , 537-556, doi:10.5194/bg-7-537-2010, 2010.

Flechard, C. R., Nemitz, E., Smith, R. I., Fowler, D., Vermeulen, A. T., Bleeker, A., Erisman, J. W., Simpson, D., Zhang, L., Tang, Y. S., and Sutton, M. A.: Dry deposition of reactive nitrogen to European ecosystems: a comparison of inferential models across the NitroEurope network, Atmos. Chem. Phys., 11, 2703-2728, doi:10.5194/acp-11-2703-2011, 2011.

Geels, C., Andersen, H. V., Ambelas Skjøth, C., Christensen, J. H., Ellermann, T., Løfstrøm, P., Gyldenkærne, S., Brandt, J., Hansen, K. M., Frohn, L. M., and Hertel, O.: Improved modelling of atmospheric ammonia over Denmark using the coupled modelling system DAMOS, Biogeosciences, 9, 2625-2647, doi:10.5194/bg-9-2625-2012, 2012.

Hass, H., van Loon, M., Kessler, C., Stern, R., Matthijsen, J., Sauter, F., Zlatev, Z., Langner, J., Foltescu, V., and Schaap, M.: Aerosol modelling: Results and Intercomparison from European Regional-scale modelling systems, Special Report EUROTRAC2 ISS, Munchen, Germany, 2003.

Horvath, L., Asztalos, M., Fuhrer, E., Meszaros, R., and Weidinger, T.: Measurement of ammonia exchange over grassland in the Hungarian Great Plain, Agr. Forest Meteorol., 130, 282-298, 2005 .
Kuenen, J., Denier van der Gon, H., Visschedijk, A., Van der Brugh, H., and Van Gijlswijk, R.: MACC European emission inventory for the years 2003-2007, TNO report TNO-060-UT-2011-00588, TNO, Utrecht, the Netherlands, 49 pp., 2011.

Manders, A. M. M., Schaap, M., Jozwicka, M., Van Arkel, F., Weijers, E. P., and Matthijsen, J.: The contribution of sea salt to $\mathrm{PM}_{10}$ and $\mathrm{PM}_{2.5}$ in the Netherlands, BOP report 500099004, PBL, Bilthoven, the Netherlands, 2009a.

Manders, A. M. M., Schaap, M., and Hoogerbrugge, R.: Testing the capability of the chemistry transport model LOTOS-EUROS to forecast $\mathrm{PM}_{10}$ levels in the Netherlands, Atmos. Environ., 43, 4050-4059, 2009b.

Manders, A. M. M., Schaap, M., Querol, X., Albert, M. F. M. A., Vercauteren, J., Kuhlbusch, T. A. J., and Hoogerbrugge, R.: Sea salt concentrations across the European continent, Atmos. Environ., 44, 2434-2442, doi:10.1016/j.atmosenv.2010.03.028, 2010.

Massad, R.-S., Nemitz, E., and Sutton, M. A.: Review and parameterisation of bi-directional ammonia exchange between vegetation and the atmosphere, Atmos. Chem. Phys., 10, 10359-10386, doi:10.5194/acp-10-10359-2010, 2010.

Milford, C., Theobald, M. R., Nemitz, E., and Sutton, M. A.: Dynamics of ammonia exchange in response to cutting and fertilising in an intensively-managed grassland, Water Air Soil Pollut., 1, 167-176, 2001a.

Milford, C., Hargreaves, K. J., and Sutton, M. A.: Fluxes of $\mathrm{NH}_{3}$ and $\mathrm{CO}_{2}$ over upland moorland in the vicinity of agricultural land, J. Geophys. Res., 106, 24169-24181, 2001b.

Neirynck, J. and Ceulemans, R.: Bidirectional ammonia exchange above a mixed coniferous forest, Environ. Pollut., 154, 424-438, 2008.

Nemitz, E., Milford, C., and Sutton, M. A.: A two-layer canopy compensation point model for describing bi-directional biosphere-atmosphere exchange of ammonia, Q. J. Roy. Meteorol. Soc., 127, 815-833, 2001.

Nemitz, E., Sutton, M. A., Wyers, G. P., Otjes, R. P., Mennen, M. G., van Putten, E. M., and Gallagher, M. W.: Gas-particle interactions above a Dutch heathland: II. Concentrations and surface exchange fluxes of atmospheric particles, Atmos. Chem. Phys., 4, 1007-1024, doi:10.5194/acp-4-1007-2004, 2004.

Nenes, A., Pilinis, C., and Pandis, S. N.: ISORROPIA: A new thermodynamic model for multiphase multicomponent inorganic aerosols, Aquatic Geochem., 4, 123-152, 1998.

Pitcairn, C. E. R., Leith, I. D., Sheppard, L. J., Sutton, M. A., Fowler, D., Munro, R. C., Tang, S., and Wilson, D.: The relationship between nitrogen deposition, species composition and foliar nitrogen concentrations in woodland flora in the vicinity of livestock farms, Environ. Pollut., 102, 41-48, 1998.

Plantaz, M. A. H. G.: Surface/atmosphere exchange of ammonia over grazed pasture, $\mathrm{PhD}$ thesis, Wageningen Universiteit, the Netherlands, 199 pp., 1998.

Schaap, M. and Denier van der Gon, H. A. C.: On the variability of Black Smoke and carbonaceous aerosols in The Netherlands, Atmos. Environ., 41, 5908-5920, 2007.

Schaap, M., van Loon, M., ten Brink, H. M., Dentener, F. J., and Builtjes, P. J. H.: Secondary inorganic aerosol simulations for Europe with special attention to nitrate, Atmos. Chem. Phys., 4, 857-874, doi:10.5194/acp-4-857-2004, 2004a.

Schaap, M., Denier Van Der Gon, H. A. C., Dentener, F. J., Visschedijk, A. J. H., van Loon, M., Ten Brink, H. M., Putaud, J.-P., 
Guillaume, B., Liousse, C., and Builtjes, P. J. H.: Anthropogenic Black Carbon and Fine Aerosol Distribution over Europe, J. Geophys. Res., 109, D18201, doi:10.1029/2003JD004330, 2004b.

Schaap, M., Spindler, G., Schulz, M., Acker, K., Maenhaut, W., Berner, A., Wieprecht, W., Streit, N., Mueller, K., Brüggemann, E., Putaud, J.-P., Puxbaum, H., Baltensperger, U., and ten Brink, H. M.: Artefacts in the sampling of nitrate studied in the "INTERCOMP" campaigns of EUROTRAC-AEROSOL, Atmos. Environ., 38, 6487-6496, 2004c.

Schaap, M., Roemer, M., Sauter, F., Boersen, G., Timmermans, R., and Builtjes, P. J. H.: LOTOS-EUROS: Documentation. TNO report B\&O 2005/297, TNO, Apeldoorn, the Netherlands, 57 pp., 2005.

Schaap, M., Timmermans, R. M. A., Roemer, M., Boersen, G. A. C., Builtjes, P. J. H., Sauter, F. J., Velders, G. J. M., and Beck, J. P.: The LOTOS-EUROS model: Description, validation and latest developments, Int. J. Environ. Pollut., 32, 270-290, 2008.

Simpson, D., Fagerli, H., Jonson, J. E., Tsyro, S., Wind, P., and Tuovinen, J.-P.: Transboundary Acidification, Eutrophication and Ground Level Ozone in Europe, Part 1. Unified EMEP Model Description, EMEP Report 1/2003, EMEP/MSC-W, 74 pp., 2003.

Skjøth, C. A., Geels, C., Berge, H., Gyldenkærne, S., Fagerli, H., Ellermann, T., Frohn, L. M., Christensen, J., Hansen, K. M., Hansen, K., and Hertel, O.: Spatial and temporal variations in ammonia emissions - a freely accessible model code for Europe, Atmos. Chem. Phys., 11, 5221-5236, doi:10.5194/acp-11-52212011, 2011.

Smith, R. I., Fowler, D., Sutton, M. A., Flechard, C., and Coyle, M.: Regional estimation of pollutant gas dry deposition in the UK: model description, sensitivity analyses and outputs, Atmos. Environ., 34, 3757-3777, 2000.

Stern, R., Builtjes, P., Schaap, M., Timmermans R., Vautard, R., Hodzic, A., Memmesheimer, M., Feldmann, H., Renner, E., Wolke, R., and Kerschbaumer, A.: A model inter-comparison study focussing on episodes with elevated $\mathrm{PM}_{10}$ concentrations, Atmos. Environ., 42, 4567-4588, 2008.

Stolk, A. P., van Zanten, M. C., Noordijk, H., van Jaarsveld, J. A., and van Pul, W. A. J.: Meetnet Ammoniak in Natuurgebieden, Meetresultaten 2005-2007, RIVM Rapport 680710001, Bilthoven, the Netherlands, 140 pp., 2009.

Sutton, M. A. and Fowler, D.: A model for inferring bidirectional fluxes of ammonia over plant canopies, Proceedings of the WMO Conference on the Measurement and Modelling of Atmospheric Composition Changes Including Pollution Transport, WMO/GAW-91, WMO Geneva, 179-182, 1993.

Sutton, M. A., Burkhardt, J. K., Guerin, D., Nemitz, E., and Fowler, D.: Development of resistance models to describe measurements of bi-directional ammonia surface-atmosphere exchange, Atmos. Environ., 32, 473-480, 1998.

Tamm, S. and Schulz, M.: Open-ocean aerosol composition obtained during 15 months on a North Sea ferry, Atmos. Environ., 37, S133-143, 2003.

Thijsse, Th. R., Duyzer, J. H., Verhagen, H. L. M., Wyers, G. P., Wayers, A., and Mols, J. J.: Measurements of ambient ammonia with diffusion tube samplers, Atmos. Environ., 32, 333-337, 1998.

Thunis, P. and Cuvelier, C. (Eds.): EURODELTA - II, Evaluation of a Sectoral Approach to Integrated Assessment Modelling includ- ing the Mediterranean Sea, EUR 23444 EN - 2008, Luxembourg: Office for Official Publications of the European Communities, 2008 .

Timmermans, R. M. A., Segers, A. J., Builtjes, P. J. H., Vautard, R., Siddans, R., Elbern, H., Tjemkes, S. A. T., and Schaap, M.: The Added Value of a Proposed Satellite Imager for Ground Level Particulate Matter Analyses and Forecasts, J. Selected Topics Appl. Earth Obs. Remote Sens., 2, 271-283, doi:10.1109/JSTARS.2009.2034613, 2010.

Van de Kassteele, J., Koelemeijer, R. B. A., Dekkers, A. L. M., Schaap, M., Homan, C. D., and Stein, A.: Statistical mapping of $\mathrm{PM}_{10}$ concentrations over Western Europe using secondary information from dispersion modeling and MODIS satellite observations, Stoch. Environ. Res. Risk Assess., 21, 183-194, 2006.

Van der Hoek, K. W.: Estimating ammonia emission factors in Europe: Summary of the work of the UNECE ammonia expert panel, Atmos. Environ., 32, 315-316, 1998.

Van Jaarsveld, J. A.: The Operational Priority Substances model: Description and validation of OPS-Pro 4.1. RIVM report 500045001, Bilthoven, the Netherlands, 156 pp., 2004.

Van Loon, M., Vautard, R., Schaap, M., Bergström, R., Bessagnet, B., Brandt, J., Builtjes, P. J. H., Christensen, J. H., Cuvelier, K., Graf, A., Jonson, J. E., Krol, M., Langner, J., Roberts, P., Rouil, L., Stern, R., Tarrasón, L., Thunis, P., Vignati, E., White, L., and Wind P.: Evaluation of long-term ozone simulations from seven regional air quality models and their ensemble average, Atmos. Environ., 41, 2083-2097, 2007.

Van Pul, W. A. J., Van den Broek, M. M. P., Volten, H., Van der Meulen, A., Berkhout, S., Van der Hoek, K. W., Wichink Kruit, R., Huijsmans, J. F. M., Van Jaarsveld, J. A., De Haan, B., and Koelemeijer, R.: Het ammoniakgat: onderzoek en duiding. RIVM Report 680150002, Bilthoven, the Netherlands, 97 pp., 2008.

Van Pul, A., Hertel, O., Geels, C., Dore, A., Vieno, M., Van Jaarsveld, H., Bergström, R., Schaap, M., and Fagerli, H.: Chapter 19: Modelling of the Atmospheric Transport and Deposition of Ammonia at a National and Regional Scale, in: Atmospheric Ammonia, Detecting emission changes and environmental impacts, Results of an Expert Workshop under the Convention on Long-range Transboundary Air Pollution, edited by: Sutton, M. A., Reis, S., and Baker, S. M. H., Springer, ISBN 978-1-40209120-9, 2009.

Van Zanten, M. C., Sauter, F. J., Wichink Kruit, R. J., Van Jaarsveld, J. A., and Van Pul, W. A. J.: Description of the DEPAC module: Dry deposition modelling with DEPAC_GCN2010, RIVM report 680180001/2010, Bilthoven, the Netherlands, 74 pp., 2010.

Vautard, R., van Loon, M., Schaap, M., Bergström, R., Bessagnet, B., Brandt, J., Builtjes, P.J.H., Christensen, J. H., Cuvelier, K., Graf, A., Jonson, J. E., Krol, M., Langner, J., Roberts, P., Rouil, L., Stern, R., Tarrasón, L., Thunis, P., Vignati, E., White, L., and Wind, P.: Is regional air quality model diversity representative of uncertainty for ozone simulation?, Geophys. Res. Lett., 33, L24818, doi:10.1029/2006GL027610, 2006.

Vecchi, R., Valli, G., Fermo, P., D’Alessandro, A., Piazzalunga, A., and Bernardoni, V.: Organic and inorganic sampling artefacts assessment, Atmos. Environ., 43, 1713-1720, doi:10.1016/j.atmosenv.2008.12.016, 2009.

Vieno, M.: The Use of An Atmospheric Chemistry-Transport Model (FRAME) over the UK and the Development of Its Numerical 
and Physical Schemes. PhD thesis University of Edinburgh, Edinburgh, UK, 2005.

Wagstrom, K. M., Pandis, S. N., Yarwood, G., Wilson, G. M., and Morris, R. E.: Development and application of a computationally efficient particulate matter apportionment algorithm in a three-dimensional chemical transport model, Atmos. Environ., 42, 5650-5659, doi:10.1016/j.atmosenv.2008.03.012, 2008.

Walcek, C. J.: Minor flux adjustment near mixing ratio extremes for simplified yet highly accurate monotonic calculation of tracer advection, J. Geophys. Res., 105, 9335-9348, 2000.

Walker, J., Spence, P., Kimbrough, S., and Robarge, W.: Inferential model estimates of ammonia dry deposition in the vicinity of a swine production facility, Atmos. Environ., 42, 3407-3418, 2008 .

Wesely, M. L.: Parameterization of surface resistances to gaseous dry deposition in regional-scale numerical models, Atmos. Environ., 23, 1293-1304, 1989.

Whitten, G., Hogo, H., Killus, J.: The Carbon Bond Mechanism for photochemical smog, Environ. Sci. Technol., 14, 14690-14700, 1980.

Wichink Kruit, R. J., Van Pul, W. A. J., Otjes, R. P., Hofschreuder, P., Jacobs, A. F. G., and Holtslag, A. A. M.: Ammonia fluxes and derived canopy compensation points over non-fertilized agricultural grassland in the Netherlands using the new gradient ammonia - high accuracy - monitor (GRAHAM), Atmos. Environ., 41, 1275-1287, 2007.
Wichink Kruit, R. J., Van Pul, W. A. J., Sauter, F. J., Van den Broek, M., Nemitz, E., Sutton, M. A., Krol, M., and Holtslag, A. A. M.: Modeling the surface-atmosphere exchange of ammonia, Atmos. Environ., 44, 945-957, 2010.

Wu, Y., Walker, J., Schwede, D., Peters-Lidard, C., Dennis, R., and Robarge, W.: A new model of bi-directional ammonia exchange between the atmosphere and biosphere: Ammonia stomatal compensation point, Agr. Forest Meteorol., 149, 263-280, 2009.

Wyers, G. P. and Erisman, J. W.: Ammonia Exchange over coniferous forest, Atmos. Environ., 32, 441-451, 1998.

Wyers, G. P., Otjes, R. P., and Slanina, J.: A continuous flow denuder for the measurement of ambient concentrations and surface fluxes of ammonia, Atmos. Environ., 27, 2085-2090, 1993.

Zhang, L., Wright, L. P., and Asman, W. A. H.: Bi-directional airsurface exchange of atmospheric ammonia: A review of measurements and a development of a big-leaf model for applications in regional-scale air-quality models, J. Geophys. Res., 115, D20310, doi:10.1029/2009JD013589, 2010. 